\title{
Comprehensive Evaluation of E-Service Quality Determinants. "Studying the Impact of these Key Quality Determinants On The Satisfaction and Loyalty of Online Jordanian Customers"
}

\author{
Mohammad Raja Salah \\ Department of Managerial and Financial Sciences, Ma'an University College, Al-Balqa Applied University, \\ Jordan
}

\begin{abstract}
The wide use of Internet and the advancement in information and communication technologies have significantly changed the way business is conducted. Over the last decade or so online shopping tendency has increased all over the world. Hence, the purpose of this study was to investigate the impact of customer service quality, system quality, information quality, security \&privacy quality, website quality, convenience quality, economic value quality and empathy quality on customer's satisfaction and loyalty "the case of online Jordanian customers". The study is based on a set of null hypotheses that hypnotizes no significance impact of these qualities on customers' satisfaction and customers' loyalty. A quantitative approach is used and relevant data was collected through structured questionnaire distributed to residents of Jordan. The relevant responses of subjects for the study consisted of 680 people. SPSS version 16 was used to for data analysis. Descriptive and inferential statistics were used for data analysis. Statistical tools were aligned with objective of the research. For this purpose, frequency tables, percentages, means and standard deviations were computed and then substantively interpreted. Inferential statistics like Pearson product moment correlation coefficient $(r)$ and linear regression were used to determine if there is a significant positive relationship existed between the independent variables and the dependent variables. The findings indicate that customer service quality, system quality, information quality, security \&privacy quality, website quality, convenience quality, economic value quality and empathy quality were found to be positively correlated and claimed statistically significant relationship with customers' satisfaction and customers' loyalty. Analysis and interpretations made at 0.05 level of significance. The study concluded that the impact of these variables is differentials as per customer's perceptions. Furthermore, service providers should concentrate on all e-service qualities to satisfy customers and earn their loyalty. Strict adherence well enable e-service providers to gain online competitive advantage and sustain their businesses in the virtual environment.
\end{abstract}

Keywords: E-Service Quality, Online, Customers' Satisfaction, loyalty. Jordan

DOI: $10.7176 / \mathrm{EJBM} / 11-12-24$

Publication date: April $30^{\text {th }} 2019$

\section{INTRODUCTION}

Now days, the field of e-service is growing fast in most emerging economies all over the world. Internet has dominated and facilitated most business activities and transactions. According to ( Li et al.,2009) the rapid development of information and communication technology, the wide spread of internet, and the availability of World Wide Web (WWW) have all become critical and necessary tools in business, therefore has a major influential impact on business world. Internet has changed the way businesses interact with their customers. The internet has become an important medium for the sale of products, goods and services (Corbett et al., 2003). Based on that the majority of customers consider internet and web pages as their main sources of information (Kim et al., 2011). Bearing this in mind, (Wan et al., 2011) stated that, the effective evaluation of customer's satisfaction and service quality is number one goal for service firms that would like to survive in a fierce competitive market place. The practical approach to Service quality evaluation differs enormously for firms, which offer electronic and online services and those, which offer traditional services. In practice, normal or as sometimes referred to as traditional services qualities refers to the quality of all non- electronic or non-Internet based dealings, transactions and so on. According to (Parasuraman et al., 1988), traditional services qualities refers to the quality of all-non- Internet based customer interactions and experiences with companies. On the other hand, e-service refers to the internet based interactions that takes place between customers and businesses followed by a comprehensive critical assessment and judgment of e-service endeavors. Hence (Santos, J. 2003), defined e-service as the overall assessment and judgment of e-service delivery in the virtual marketplace. The adaption of e-commerce enables businesses to gain a competitive advantage as well as increased sales and larger profits. In agreement with this statement are the studies conducted by (Yang, Z. 2001) and (Zeithaml, V.A. 2002), in which they concluded that businesses with vast experience and notable success in using e-commerce are beginning to realize that the key determinants of success or failure are not merely web site presence, more product and services choices with 
reduced cost and a competitive lower prices but also include the electronic service quality (e-service quality). The highest proportion of current research concentrates on traditional services qualities. In contrast, only limited number of academic articles deal directly with how customers assess e-service quality (Parasuraman et al., 2005). According to (Asubonteng et al., 1996), service quality can be seen as the gap between customers' perceptions of the service received and their expectations about service performance prior to the service offering. If service performance does not meet expectations, people will think that the service quality is low. However, when performance goes over expectations, the perception of the service quality is higher (Connolly, 2007). Consequently, customers ' expectations are crucial in evaluating service quality. Therefore, it is agreed that Careful considerations of customers perceptions, assessments and evaluations are crucial elements of any successful business strategy, being it on line or otherwise. Supportive study to this phenomenon is (Collier and Bienstock, 2006), in this regard, e- service quality can be differentiated as comprehensive consumer appraisal and assessments about the excellence of e-service provision in the implicit marketplace are available. However, deep reading of related research shows general agreement in that, service quality is more difficult for customers to evaluate as compared to the quality of tangible goods offered in

Conventional marketplace (Kueh and Voon, 2007). As a result, several different determinants, scales and dimensions have been developed by researchers to measure the service performance, delivery and interaction aspects of e- service quality. The most well-known, adopted and tested measure is the SERVQUAL instrument developed by (Parasuraman et al., 1985). This instrument has 97 items in ten distinctive dimensions of service quality and later on (Parasuraman et al., 1988); the authors have brought down the dimensions from 10 to five and the items from 97 to 22 . The dimensions comprise tangibles that include physical facilities, functional appeal and employee appearance; reliability that includes the ability to conduct promised service in an accurate manner and in a trustworthy way; assurance including personnel recognition that encourages user confidence and trust; and, lastly, empathy that includes care provision and paying individual attention to customers. From that time, the five service quality dimensions have become the basis for universal service quality measurement (Yang and Jun 2002). Majority of researchers have identified several dimensions of e-service quality. Their proposition is mainly based on conceptualized context and lacks consistency in the proposed. According to (Agrawal, 2007), substantial research papers provide a generalized scale developed using a variety of industries; also, comparative studies to find the best approach (discrepancy/gap, or, perception based) to measure e-service quality are nonexistent. Accordingly, there is a predominance of perception based measurement approaches only. Whereas, the adoption of comparative study suggests that discrepancy/gap based approach is superior to the perception-based approach in measuring e-service quality. In contrast, a very limited number of research paper concentrate on how customers assess e-service and what are the appropriate dimensions of the quality of e-service delivery (Carlson and Aron 2010). More to say, even with the increased acknowledgement of online service, issues such as how online service quality is defined, its measurement and its determinants are still unresolved (Kenova and Johansson, 2006). Based on the above rational, this paper addresses the issue of e-service quality in the online shopping environment. Therefore, the purpose of this paper is to provide a comprehensive evaluation of e-service quality determinants based on online Jordanian customers perceptions. Multidimensional construct consisting of combined eight quality determinants is proposed for measuring effectiveness of e-service quality: customer service quality, system quality, information quality, security \&privacy quality, website quality, convenience quality, economic value quality and empathy quality.

\section{STATEMENT OF THE PROBMLEM}

Jordan is one of the Middle Eastern country with rising population. It is estimated that more than $75 \%$ of population is computer laterite. Internet revolution and its wide spread, technology advancement, the rapid development of ecommerce, globalization of the market have and the rising phenomena of e-banking services fundamentally changed the way customers interact with their environment and consequently have laid good conditions for online shopping. According to ( Zhilin et al., 2004), online business is in positive trend this growth is due to the following facilities" online shopping environment provides infinite selection, information screening, reliability and product comparison which enable the customers saving their time consumption and quick decision making. It also makes a convenience situation for doing business to the consumers in such a way that reducing the role of physical geography for the consumers. One of the reason for this drastic success is the support given by the retailer too through i) aggressive merchandising ii) discounting through flash sales and iii) loyalty and reward programs". Other noticeable benefits of online endeavors include low prices, low switching costs, the extreme number of goods and services available on the web pages and the variety of e- payment facilities provided to customers by ebanking. On their part, many e-businesses are going for extreme exploitation and creation of business opportunities on the internet. (Bahram et al., 2012), stated that Companies spend a lot of money on their websites to provide their customers with traditional functionality and a more integrated marketing stream with the hopes of entering customers to purchase goods on line. The key determinants of success or failure for e-commerce companies are not merely web presence or low price but delivering right quality of e-service that causes sophisticated online 
customers pay a higher price. In order to gain competitive advantage in the e- environment and gain a reasonable share of the e-market sellers should pay their at most attention to the issue of e-service qualities and associated determinants. Based on that it became urgent to effectively evaluate e-service qualities determinants and investigate the impact of these qualities determinants on customer's satisfaction and loyalty "the case of online Jordanian customers".

\section{PURPOSE OF THE STUDY}

The main purpose of this study is to investigate the impact of e-service qualities determinants on customers' satisfaction and loyalty "the case of online Jordanian customers". Based upon the problematic nature and investigation relevance of e-service qualities its associated determinants for internet shopping, the propose of this research paper is developed (based on a multidimensional model) and then a practical evaluation of all selected combined e-service qualities is provided; hence give better understanding of the conditions that are most pressing in predicting consumers' behavioral intention to purchase over the internet.

\section{OBJECTIVES OF THE STUDY}

Based upon the above listed statement of the problem and the utilization of detailed quantitative data collected from respondents in Jordan, this study has the following specific objectives:

1. Evaluate the impact of combined e-service qualities on customers' satisfaction and loyalty.

2. Evaluate the impact of customer service qualities on customers' satisfaction and loyalty.

3. Evaluate the impact of system qualities on customers' satisfaction and loyalty.

4. Evaluate the impact of information qualities on customers' satisfaction and loyalty.

5. Evaluate the impact of security \&privacy qualities on customers' satisfaction and loyalty.

6. Evaluate the impact of website qualities on customers' satisfaction and loyalty.

7. Evaluate the impact of convenience qualities on customers' satisfaction and loyalty.

8. Evaluate the impact of economic value qualities on customers' satisfaction and loyalty.

9. Evaluate the impact of empathy qualities on customers' satisfaction and loyalty.

10. Evaluate the impact of customers' satisfaction on loyalty.

11. Provide practical suggestions and recommendations for all parties involved in online dealings.

\section{STUDY RESEARCH QUESTIONS}

To accomplish the objectives of the study, the following central questions were addressed:

a) Is there a relationship between e-service qualities and customers' satisfaction and loyalty?

b) Is there a relationship between customer service qualities and customers' satisfaction and loyalty?

c) Is there a relationship between system qualities and customers' satisfaction and loyalty?

d) Is there a relationship between information qualities and customers' satisfaction and loyalty?

e) Is there a relationship between security \&privacy qualities and customers' satisfaction and loyalty?

f) Is there a relationship between website qualities and customers' satisfaction and loyalty?

g) Is there a relationship between convenience qualities and customers' satisfaction and loyalty?

h) Is there a relationship between economic value qualities and customers' satisfaction and loyalty?

i) Is there a relationship between empathy qualities and customers' satisfaction and loyalty?

j) Is there a relationship between and customers' satisfaction and loyalty.

\section{SIGNIFICANCE OF THE STUDY}

Internet has significantly revolutionized the retail industry in the last few years in particular online shopping. In the early stage of internet introduction retailers competed with each other using traditional methods like lower prices, sales discounts and easier terms of payment. However, with increased numbers of customers buying over the internet these traditional methods are no longer appropriate. Therefore, e- businesses operating in the internet market need to find alternative ways to attract customers to their online shopping service. (Oliveria et al., 2002) stated that electronic service (e-service) might be the key to long-term advantage in the digital times, and is becoming even more critical for companies to retain and attract customers in the digital age. The association between e-services qualities and the extensive increase in online shopping in Jordan has not received the proper attention by service providers, online customers or by academics. Therefore, it is hoped that this study would provide better understanding of e-service qualities that may influence and persuade customers to do their shopping online. Hence, provide additional contribution to existing literature on the topic. Furthermore, it is hoped that adoption of a multidivisional model for e-service qualities would deviate attention from a conceptualization mode to measurement and evaluation modes. Unlike most conventional studies on e-service qualities, this study explicitly considered the most important demographic factors that may explain the behavioral attitudes towards online shopping. The methodology followed in this study can be used by other researchers to explain in depth the impact of each e-service quality on customer's satisfaction and loyalty. Finally, it is hoped that the findings of this 
study would be of great benefits to researchers, scholars, customers, managers and others who have interest in this topic.

\section{SCOPE OF THE STUDY}

Deep revision of the literature suggests that internet usage is continuing to increase. E- enterprises need to keep up not only the quality of their goods and services but also the quality of their promotion, condition and facilities offered on their web -site. Effective e-commerce strategies, sophisticated e-total quality management, strategic emarketing planning,

Careful understanding of the ever changing customers' needs and wants, accurate diagnosis of customers e- buying behavior and critical analysis of e-service qualities that include: customer service quality, system quality, information quality, security \&privacy quality, website quality, convenience quality, economic value quality and empathy quality are crucial to understanding the current phenomena of online shopping that is spread not only in Jordan but also worldwide. The Comprehensive Evaluation of E-Service Quality Determinants. "Studying The Impact of these Key Quality Determinants on Satisfaction and Loyalty of Online Jordanian Customers" is the subject scope of this study. The extended list of demographic factors is considered as categorical variables in the study. The geographical scope of this study is Jordan. Jordan is a Middle Eastern country with a population of approximately 11 million. Jordan is a country, which is highly opened to the external world and is considered among the advance country in terms of information technology employment and internet usage in proportion to its population. The target respondents involved in this study are 680 residents of Jordan randomly selected from all over Jordan. The target respondents are composed of all ages, income, and computer literacy and so on. Time constrains, logistical issues, financial resources, geographical representation of scattered areas, respondent's literacy levels and over all respondents' cooperation were important and pressing constraints that affected the conduction of this study. However, these constraints with help of expert colleagues were adequately dealt with so as not to predetermine or compromise the overall findings of the study.

\section{LITERATURE REVIEW}

\subsection{E. Service Quality}

The emergence of internet has changed the way businesses operate. The internet and its associated application is an extremely important ingredient. According to ( Neghab et al., 2013), the extensive use of internet, the development of information technology; offering internet services; internet and network total management issues and providing optimal service quality are considered as important issues. These qualities set solid ground for eservice quality improvement as well as the improvement of enterprise efficiency, competitiveness and attractiveness in the virtual market (Mekovec and Kero, 2007). E- Service is any service that is delivered to current customers or potential customers through the web pages. (Musiime and Malinga, 2011) defines e- service quality as the difference between the service that a customer or a user of a particular web site expects and the one actually provided by the web site. (Madu and Madu,2002) support the previous statement by saying that e-service quality has become an important differentiator for e-business success because it is the extent to which an e-business service provider effectively and efficiently manages customer interactions and meets their expectations. The gap between expectations and real provisions is best illustrated by the work of (Zeithaml et al., 2002), here it is stated that, service quality is the confirmation or disconfirmation experience between customer expectations and the actual services received. The higher the disconfirmation gap, the poorer the customer is perceived service-quality level. Narrowing the confirmation gap can help improve the perceived service quality. Furthermore, improving the confirmation experience with the reliability, assurance, responsiveness, empathy and tangibility of traditional service can lead to enhanced customer satisfaction (Parasuraman et al., 1988). The successful delivery of these important features can ultimately lead to customer satisfaction. Therefore, although the methods to effectively measure e-service quality vary with products increasing customer satisfaction is an important goal towards achieving e-business success. Many authors regarded e-service delivery as a dynamic process, so measuring it requires an integrative multidimensional approach. In reality measuring e-service quality is a challenge to the ebusiness because it involves a wide range of attributes including reliability, access, responsiveness, empathy, assurance, ease of navigation, etc. (Kim and Lennon,2010). The majority of current literature and practical studies measuring e-service quality provided empirical evidence that, e-service quality is a multidimensional construct. In their empirical study (Zeithaml et al., 2002) developed the e-SERVQUAL instrument for measuring e-service quality with seven dimensions: efficiency, reliability, fulfillment, privacy, responsiveness, compensation, and contact. Among them, the dimensions of efficiency, reliability, fulfillment, and privacy form the core eSERVQUAL scale, this scale can be used to measure customers ${ }^{\text {ee }}$ perceptions of service quality as delivered by online service. Effective attendance and proper e-service quality management is a must, otherwise as stated by (Lee and Lin, 2005) numerous online institutions wilt because of poor e-service quality management. 


\subsection{Customer Service Quality}

Deep study of recent research has demonstrated that customer's service quality influences most customers buying decisions. Noticeably service providers have concentrated more on the conventional marketing approaches in their attempt to increase their profits and market share. Unfortunately customers service quality" within the context of e-service" is somehow neglected in the last few years (Yang and Jun 2002), and only recently these findings have been applied to the concept of e-commerce (Wolfinbarger and Gilly, 2003). According to (Dholakia and Zhao, 2010) customer service quality has strong influence on overall online customer satisfaction. (Wiertz et al., 2004) stated that, customer service quality is one of the most important antecedent of customers' satisfaction. Furthermore, two issues are of equal importance in the segment of on line shopping: issue one is evident in (Wang and Hui, 2003) in which he said that the delivery of quality customers' services is essential for the success and survival of in today's global competitive environment. Issue two, on the other hand, prevails in (Yang, Z. 2001) which states that for online customers, high standard e-service quality is the means by which the potential benefits of the internet can be realized. In order to give full exploration of the above two issues, the following measures are proposed by the current study: initial contact, speed of response, fulfillment (completion of service), prompt delivery and assurance.

\subsection{System Quality}

System qualities are among the most important measures that are used to assess customer's satisfaction in the eretailing industry. A previous study (Stacie et al., 2008) has demonstrated the positive relationship between service quality, information quality and system quality and satisfaction. In general system quality has been evaluated with respect to various notions such as convenience, flexibility, integration, response time, language, etc. (Livari, 2005). Other researchers have addressed other notions like ease of use, ease of learning, system features, sophistication, customization and so on, (Sedera et al.,2004). Literature review regards system quality as a multi-attribute construct with many concepts embodied in it. According to (McKinney et al., 2002) system quality is a multiattribute construct, including access, usability, entertainment, hyperlinks, navigation, and interactivity. The current study adds the following attributes: system availability, accessibility, functionality, efficiency, infrastructure, accountability, creditability, competitiveness, courtesy and competence. These attributes need exploration in terms of their impact on customer satisfaction and loyalty in the area of online shopping.

\subsection{Information Quality}

It is assumed that information quality plays important role in motivating customers to make their purchases online. Customers tend to be happier and more satisfied if they are provided with the valuable and accurate information. According to (Ahituv, 1980) customers perception regarding the issue of information quality tend to be positive if information measures like accuracy, timeliness, relevance, aggregation and format are of a positive nature. (McKinney, 2002) stated that both "service providers and online customers" have a notable division regarding the issue of information quality. Online investors and service providers care more about market and product information accuracy and timeliness. In contrast, online customers are concerned with buying quality products at the lowest price. Thus, information relevance and aggregation are more important to them. Another study suggests that, information quality is an essential element of e- business success (Liu et al., 2001). More to say customers satisfaction is more if website qualities is coupled with effective information qualities such as database content, system flexibility and a user friendly interface referred to as" Front-end systems" (Emery, 1971) ; system reliability, bandwidth design and system response time referred to as" Back-end systems" (Hamilton and Chervany,1981) ; and "Middleware" integrates diverse front- and back-end systems and optimizes the overall performance of the entire system (DeLone and McLean, 2003). Despite the importance of information qualities and its impact on website acceptance (Peterson and Merino, 2003); not enough empirical research is done in this field (Kim and Lennon 2010). Stemming from this end, the current study proposes six additional important measures: information reliability, information content, information availability, information adequacy, and information honesty and trustworthiness. These notions need exploration in terms of their impact on customer satisfaction and loyalty.

\subsection{Security and Privacy Quality}

The security and privacy issues have earned a great attention in the current literature covering online services including online shopping. (Parasuraman et al., 2005) defined privacy as the degree to which the site is safe and can effectively protect customers or users' information; hence influencing users' evaluations of websites as well as their satisfaction toward the websites (Branscum and Tanaka, 2000). Other researchers like (Tianxiang and Liu, 2010) defined "privacy or security" as the ability of the website to keep customers' information secret and payments safe. Security on the other hand, can be seen as the practical techniques that are used to give assurance to customers that all their e-dealings is safe. According to (Zhang et al., 2006) security issues in online services have been noted to be a significant problem for many consumers, furthermore, security issues affect customer satisfaction with e- 
services, making it necessary for organizations to ensure that customer data is protected. The notion of security affect the level of trust and hence influences the likelihood of conducting business with the organization being it online or otherwise (Yang and Jun 2008). (Amoroso et al., 2008) said that, lake of trust is one of the most frequently cited reasons for customers not shopping on the internet; they also stated that security and privacy have an impact on customers trust in shopping on the internet. To conclude the apprehensions of the customers regarding the security for online transactions and authenticity of goods are curtailing the success of the e-shopping model. Many measures can be adopted to further enhance the security of e-service systems for example "passwords, personal identification numbers, e-signatures and digital certificate associated with a smart card system (Hutchinson and Warren, 2003). Security can also be assured by providing a privacy statement and information about the security of the shopping mechanisms and by displaying the logos of trusted third parties. For example, displaying trusted third party logo guarantees a certain level of security protection and has been shown to significantly influence how consumers regard the trustworthiness of e-vendors (Jiang et al., 2008). The current study proposes four additional important factors: safety of the website, customers' protection, online trust and transactional security and these notions need exploration in terms of their impact on customer satisfaction and loyalty.

\subsection{Web Site Quality}

The last few years have witnessed increased numbers of research papers on website quality as a determinant of customer satisfaction and as a dominant factor, that drives customers to buy or repeat purchase. (Gummerus et al., 2004) referred that the user interface is the channel, where the users in relation to e-service providers. According to (Kim and Lee, 2002), the appeal the user interface design presents to their customers is illustrated in the form of web site design. Elements of physical design such as information design, navigation, layout and appearance that is the software component are important but insufficient. The elements of the hardware also should be considered to allow customers to have easy access to the site. (Gommans et al., 2001) indicated that online consumers would be more pleased with websites that were localized to their particular cultural preferences. Furthermore, extensive studies is found and link customer satisfaction and quality of the web site design. (Wolfinbarger and Gilly, 2003), is a recent empirical study confirmed that web site factors are strong predictors of customer quality judgments, satisfaction, and loyalty for internet retailers. Website quality comprises factors like interactivity, customization, care, cultivation, choice, community, character and convenience (Srinivasan et al., 2002). interactivity, novelty and complexity (Huang, 2003); community, individualization, free services, technical integration and convenience (Wirtz and Lihotzky, 2003); information quality, connectivity playfulness, learning and interactivity (Chiu et al., 2005);appearance, content quality, specific content and technical adequacy (Liao et al.,2006); website design, communication, order fulfillment, security/privacy, promotion and merchandising (Jin and Park, 2006) ; and, transaction speed, information quality security and user-friendliness (Shih and Fang, 2006). The current study proposes five additional important factors: aesthetic design, customization, enjoyment, interactivity and content. These additional factors are not extensively studied and need exploration in terms of their impact on customer satisfaction and loyalty.

\subsection{Convenience Quality}

Much of the present academic work on e-service tend to of a comparative nature. Traditional service quality dimensions and web interface quality dimensions are normally compared as the starting point. The dimension of convenience is no different from other dimensions. In the traditional trading environment, convenience may include things like easy terms of payment, easy access, punctual delivery times; meeting individual needs and so on. On the other hand, convenience in the online environment is rather different. The e-environment is dominated by the extensive use of technologies and these technologies are expected to yield various benefits to online customers. According to (Van Riel et al., 2001), these benefits include convenience, saving time and money, avoiding interpersonal interaction and being in control. It is generally accepted that customers demand verities of products at affordable prices; they also expect more convenience in the online shopping. This notion is addressed in the work of (Martinelli and Balboni, 2012). According to them Customers' demand does not only mean basic products or affordable prices, but also convenience shopping experience. For example, online convenience stores should employ user reviews and recommendations to help customers make rational impulse purchase decisions thereby increasing customer's satisfaction (Lee and Kacen, 2008). The current study proposes five additional important factors that may shed light on the impact of convenience qualities on customer's satisfaction and loyalty. These suggested factors include attentiveness, responsiveness, and ease of use, innovativeness and customer technical support.

\subsection{Economic Attributes}

Many organizations are exploiting and creating business opportunities on the internet. Huge amounts of money are spent on the creation and development of attractive websites to attract customer's attention to and persuade 
them to make their purchases on line and consequently gaining more economic returns. According to (Bahram et al., 2012) e-retailing is promoted widely as a convenient avenue for shopping. Online shopping is expected to yield many benefits for both service providers and online customers. (Peterson et al., 1997) identified that shopping online can economize on time and effort by making it easy to locate merchants, find items, and procure offerings within the convenience of their home. Online stores have a wider variety of goods available in their warehouses compared to traditional retailing stores and therefore have quick access to more preferred goods and services are not constrained by limited physical store space (Christodoulides and Michaelidou, 2011). (Khalifa and Liu, 2006) stated that, online shopping is perceived as advantageous because it offers convenience and cost savings. (Morton, 2006) further stated that online convenience as a part of customer service can lower transactional costs, particularly for busy or uninformed customers who may have high transaction costs. These costs economies have a considerable impact on both firms' competitive edge (Sun, 2010). Furthermore, many research papers found that these benefits have impact on customer's perceived values and hence influenced customer's satisfaction and loyalty (Wan et al., 2011). The current study proposes three additional important factors that may shed light on the impact of economic qualities on customer's satisfaction and loyalty. These factors include perceived value, compensation and cost of service.

\subsection{Empathy}

According to (Tan et al., 2008), empathy concerns with users' attitudes that the online portal is giving them individualized consideration and it gives them best advantages on a basic level through the coordination of both delivery mechanism and service content. Literature on empathy shows common agreement in the point that the eenvironment and the virtual e-service process is generally categorized by the least amount of direct human contact and interactions. However real and objective analyses of empathy shows some element of human contact and involvement in the e-service course. (Li et al., 2009) pointed that, characteristics of empathy aspects include: great individual consideration, satisfactory contacts, and address grievances friendly and reliably respectful. Furthermore, understanding customer's needs and proper catering for such needs should be embodied in any eservice strategies. (Parasuraman et al., 1985) concluded that empathy is caring for individual considerations and needs that the firm introduce to its customers. According to (Ananth et al., 2010), the offerings include individual attention; suitable working hours; and providing personal attention to their customers; overall best convenient services, understand customers required specific needs and effective responses to customers. (Ndubisi, 2006) stated that classified consumer satisfaction can be accomplished by offering customized, adaptable and supple services to suit the requirements of consumers. Therefore, one can conclude that empathy is important in customer's perception of the e-service quality without face-to-face interactions. The current study proposes four additional important factors: Customers' Individualization, personalization-communication and effective feedback management demonstrate empathy to customers. These additional factors need exploration in terms of their impact on customer satisfaction and loyalty.

\subsection{Customers satisfaction}

Determining the level of customers, 'satisfaction is a tricky area. Under conventional marketing approaches customers 'satisfaction can be defined as a consumer's feeling of a pleasure or disappointment resulting from comparing a product's perceived performance (or outcome) in relation to his or her expectation ( P. Kotler,2010). One good definition of customers 'satisfaction is put forward by (C.C. Lin, 2003) "Customer satisfaction is defined as a result of a cognitive and affective evaluation, where some comparison standard is compared to the actually perceived performance. If the perceived is less than expected, customers will be dissatisfied. On the other hand, if the perceived performance exceeds expectations, customers will be satisfied." Both definitions stress the importance of Customer satisfaction and links it with firm's performance. According to ( Fasanghari et al., 2008) effective and careful customer satisfaction investigation is a very crucial precondition for e-commerce area to win market competition. Despite its trickiness customer, satisfaction is regarded as an area of concern for all parties in the market place. (Mozaheb et al., 2015) stated that, customer satisfaction is one of the most important variables for long-term business success. Customer satisfaction reduces the costs for attracting new customers and dealing with poor quality, defects and complaints (Michel et al., 2009). (Williamsand Neumann, 2011) noted that customer satisfaction has been found to improve the long-term financial performance of firms, increases profitability and enhances firm's market value. In reality, customers will be attracted to the business only when providing good quality, time delivery, low prices and promotion offers (Reibstein, 2002). Analytical research like (Wang and Ming 2003) suggests that in both conventional markets and e-markets the level of consumer satisfaction is determined by set of factors like the quality of services, the price level, and the purchasing process. Furthermore, nine service quality factors were said to affect e-satisfaction through content analysis of online customer comments; these factors include" 1 . General feedback on the web site design, 2. Competitive price of the product 3. Merchandise availability 4. Merchandise condition 5. On-time delivery 6. Merchandise return policy 7. Customer support, 8. E-mail confirmation on customer order and 9. Promotion activities". This brief literature 
review shows that consumer satisfaction is a critical predictor for customer loyalty; profitability of the retailer is marketing activities, purchasing and re-purchasing behavior and the retailer's performance (Kuo et al., 2009). Finally, plenty of research like (Cass, 2001) argues that a satisfied customer is expected to show brand loyalty; and customer e-loyalty is influenced by satisfaction (Flavián et al., 2006).

\subsection{Customers Loyalty}

In conventional market place, customer loyalty can be defined as customers' attitudinal component represents notions like: repurchase intentions, purchasing additional products or services from the same company, recommending it to others and resistance to switch to other competitors (Cronin et al., 1992). Other researchers like (Akbar and Parvez, 2009) concluded that customer loyalty expresses an intended behavior or attitude towards the company goods, services or the company itself. According to existing literature the measures of customer loyalty is not straight forward. (Chaudhuri and Holbrook, 2001) argued that, loyalty can be examined through behavioral loyalty "Behavioral loyalty is customer willingness to continue a relationship and repurchase the product". Another measure of loyalty is "attitudinal loyalty" which is the level of the customer's attitudinal advocacy and psychological attachments to the service provider (Rauyenruan and Miller, 2007). Further measures is composite approach. According to (Uncles et al.,2003) composite approach is regarded as an integration of behavioral measures (in the sense of exclusive purchase, hard-core loyalty, repeat purchase probability, share of category requirements, etc.) and attitude (with reference to brand preference, liking, commitment, intention-tobuy. In the context of e- business loyalty can be defined as a customer's favorable attitude and commitment towards the online retailer that result in repeat purchase behavior (Anderson and Srinivasan, 2003). Other researchers like (Li 2009) defines e-loyalty as the willingness to observe and to revisit a website or to make a transaction in the future. Customer loyalty plays a significant role in achieving organizational success, sustainability, reduces costs of operations, acts as a source of information through positive word of mouth, hence establishing stronger relations with online service providers. Many research papers have investigated the impact of satisfaction on e-loyalty and their conclusions confirmed that satisfied customers tend to build a positive closer relationship with the online retailers. (Zins, 2001) states that loyalty can be developed through high level of customer satisfaction. (Cyr, 2008) found that satisfaction with E-commerce websites is a key factor in maintaining customer loyalty. Further practical benefits of e-loyalty include fast feedback on last purchases experiences, loyal customers are more accessible than new users of websites and the availability of information on existing databases makes information cross-referencing easier. According to (Reid and Reid, 1993) this knowledge permits both suppliers and service providers to concisely target the repeat segment of online market and solicit direct responses to promotions.

\section{RESEARCH THEORATICAL FRAMEWORK}

There is tendency among todays' customers to do their shopping online. The wide spread of internet, the availability of information technologies, the advancement of telecommunication system and the extreme use of social media made online retailing and shopping easier. The research framework is illustrated in a diagram form based on the extensive literature review on the topics of e-service qualities and online shopping. In this research, it is theorized that the independent variables such as customer service quality, system quality, information quality, security \&privacy quality, website quality, convenience quality, economic value quality and empathy quality had a positive impact on the dependent variables that include customer's satisfaction and customer's loyalty. Figure (1) below illustrates the theoretical framework of this study. The diagram shows all possible constructs that might have impact on customer's satisfaction and customer's loyalty. 


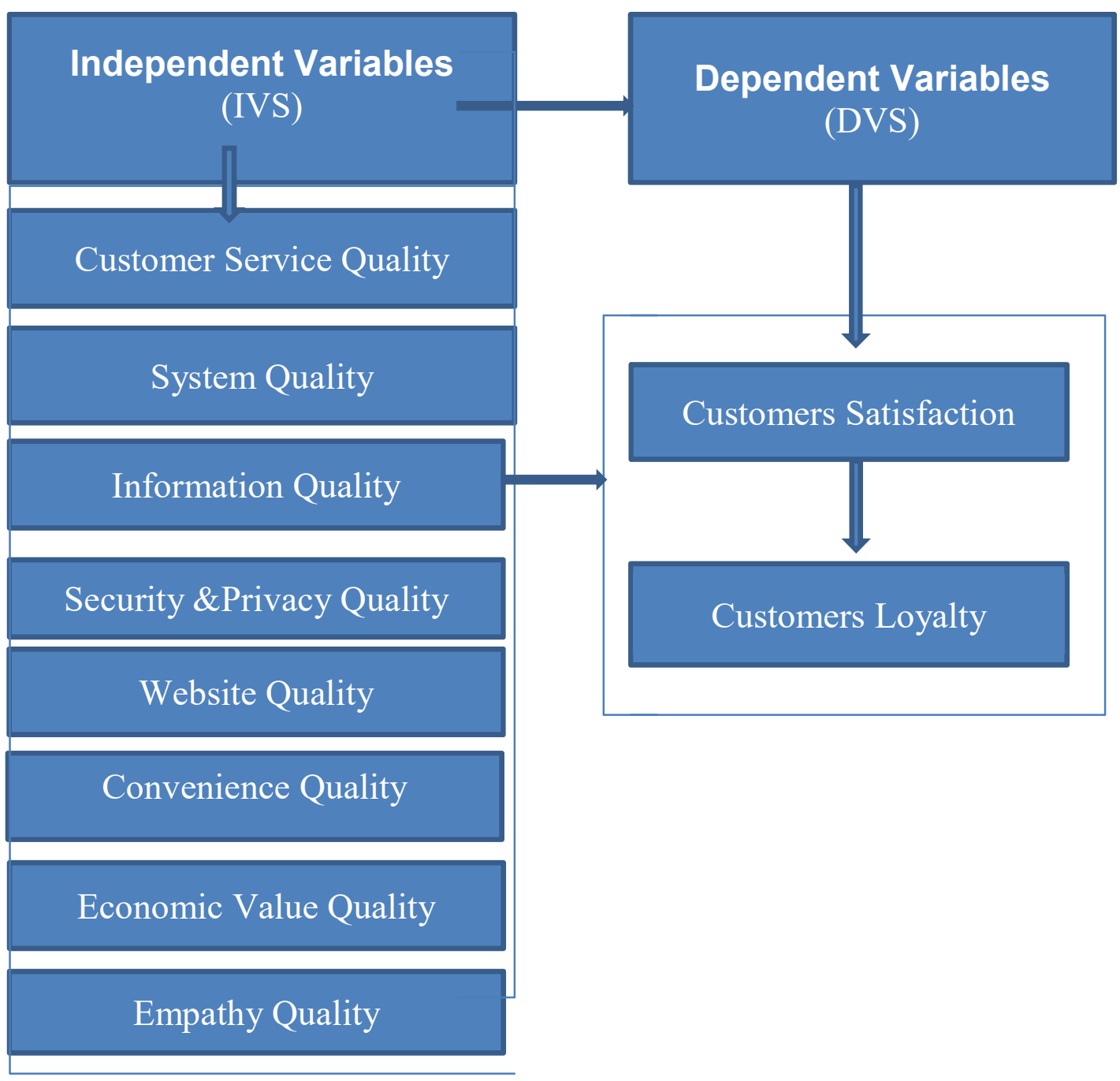

\section{Figure (1): Research Theoretical Framework}

\section{HYPOTHESES OF THE STUDY}

Hypothesis development is very crucial. Hence, the acceptance or rejection of the set hypothesis determine the significance of the study. Based on the deep review of literature related to the study and the above theoretical framework the hypotheses of this study are as follows:

Ho: Customer Service Quality has no positive significant influence on customer's satisfaction and customer's loyalty

H1: Customer Service Quality has a positive significant influence on customer's satisfaction and customer's loyalty Ho: System Quality has no positive significant influence on customer's satisfaction and customer's loyalty H2: System Quality has a positive significant influence on customer's satisfaction and customer's loyalty Ho: Information Quality has no positive significant influence on customer's satisfaction and customer's loyalty H3: Information Quality has a positive significant influence on customer's satisfaction and customer's loyalty Ho: Security \&Privacy Quality has no positive significant influence on customer's satisfaction and customer's loyalty

H4: Security \&Privacy Quality has a positive significant influence on customer's satisfaction and customer's loyalty

Ho: Website Quality has no positive significant influence on customer's satisfaction and customer's loyalty H5: Website Quality has a positive significant influence on customer's satisfaction and customer's loyalty 
Ho: Convenience Quality has no positive significant influence on customer's satisfaction and customer's loyalty H6: Convenience Quality has a positive significant influence on customer's satisfaction and customer's loyalty Ho: Economic Value Quality has no positive significant influence on customer's satisfaction and customer's loyalty H7: Economic Value Quality has a positive significant influence on customer's satisfaction and customer's loyalty Ho: Empathy Quality has no positive significant influence on customer's satisfaction and customer's loyalty H8: Empathy Quality has a positive significant influence on customer's satisfaction and customer's loyalty Ho: Customer's satisfaction has no positive significant influence on customer's loyalty H9: Customer's satisfaction has a positive significant influence on customer's loyalty

\section{RESEARCH METHODOLOGY}

\subsection{Research Design}

Survey research design is employed on online customers. A well-structured questionnaire is used to collect primary data directly from respondents. Quantitative approach is used in this current study to find answers to questions through quantitative analyses of data, which is later presented in figures and numbers for easier readings and interpretations. . Quantitative approach has the advantage of allowing researchers to interact and gather data directly from participants. In addition real life references, phenomena and implications regarding the impact of customer service quality, system quality, information quality, security \&privacy quality, website quality, convenience quality, economic value quality and empathy quality on customers' satisfaction and customers loyalty are also considered. The selected method has many advantages: first, it is known for its convenience and compatibility in dealing with present study problems and its set questions. Secondly, the selected method has the ability to reach and collect empirical evidence from wider group of the population. Finally, the used method is $\mathrm{s}$ known for its economies in terms of time and resources.

\subsection{Target Population}

According to (Saunders et al., 2003) "a population" relates to the entire set of data that is of special interest to the researcher, and the "target population" refers to the group of people or objects from which the sample is be taken. As it is not feasible to collect data for the entire statistical population. The sample that is considered representative of the population was drawn from various data bases of online customers scattered across the country of Jordan. Based on that, the target population is set at 1000 people and it includes all categories that represent the entire population of Jordan. The targeted population comprises usual citizens; students at school and university levels, expatriates, homemakers and workers were all targets of the study. The target population characteristics are summarized as shown in table (1).

Table (1): Distribution of Target Population

\begin{tabular}{|r|c|c|}
\hline \multicolumn{1}{|c|}{ Population Composition } & Numbers & Percentages \\
\hline 1. North of Jordan - Online customers & 4700 & 0.470 \\
\hline 2. South of Jordan - Online customers & 2600 & 0.260 \\
\hline 3. West of Jordan - Online customers & 2000 & 0.200 \\
\hline 4. East of Jordan - Online customers & 700 & 0.700 \\
\hline Total Target Population & $\mathbf{1 0 0 0 0}$ & $\mathbf{1 0 0}$ \\
\hline
\end{tabular}

\section{Source: Prepared By Researcher 2019}

\subsection{Study Sample Size}

Sample size is defined as, the appropriate number of respondents that should be selected from the target population. The selected sample size should be considered convenient, sufficient and representative of the target population. The sampling procedure used in this study is Non- probability sampling and for that purpose, convenience sampling is adopted. According (Raosoft, 2004) 200 respondents or more is considered convenient, sufficient and representative for confidence level of $95 \%$ with a margin of error of $5 \%$ for a sample population size of 250,000 . Applying this to the present study with identified target population size of 10000 , the sample size of 1000 respondents is considered sufficient and meets the above criteria. 
11.4. Research Instrument

The current study used two instruments to collect needed relevant data:

\section{4(a). Primary Data}

Primary data is collected using a well-structured questionnaire that contains relevant questions in relation to online shopping in Jordan. The questionnaire used in this study intended to allow respondents to give direct, standard, unbiased, relevant and objective responses. The use of structured questionnaire allows the presentation of information in a tabulated numeric way. Despite the above-mentioned benefits questionnaires survey methods have several well-known limitations, for example lackadaisical attitude of respondents, non- attendance and lack of cooperation. Before distribution, the instrument was referred for external judgment to ensure consistency, objectivity and validity. The distributed questionnaire comprises ten sections:

Section (1): Contains ten items seeking demographic data such as gender, age, educational equalizations, annual income, residential area, computer literacy, internet accessibility, internet usage, online shopping experience and occupation.

Section (2): Contains five items that seek to collect data about the impact of customer service quality on customer's satisfaction and customer's loyalty.

Section (3): Contains ten items that seek to collect data about the impact of system quality on customer's satisfaction and customer's loyalty. Section (4): Contains six items that seek to collect data about the impact of information quality on customer's satisfaction and customer's loyalty.

Section (5): Contains four items that seek to collect data about the impact of security \&privacy quality on customer's satisfaction and customer's loyalty.

Section (6): Contains five items that seek to collect data about the impact of website quality on customer's satisfaction and customer's loyalty.

Section (7): Contains five items that seek to collect data about the impact of convenience quality on customer's satisfaction and customer's loyalty.

Section (8): Contains three items that seek to collect data about the impact of economic value quality on customer's satisfaction and customer's loyalty.

Section (9): Contains three items that seek to collect data about the impact of empathy quality on customer's satisfaction and customer's loyalty.

Section (10): Contains two items that seek to collect data about the impact of customer's satisfaction on customer's loyalty.

Items included in sections (2-11) are shown in table (2)

Table (2): List of Instrument Items Used

\begin{tabular}{|c|c|c|c|c|c|}
\hline \multicolumn{3}{|c|}{ Customer Service Quality } & \multicolumn{3}{|c|}{ System Quality } \\
\hline Section & Item \# & Description & Section & Item \# & Description \\
\hline \multirow{6}{*}{2} & 1 & Initial Contact & \multirow{6}{*}{3} & 1 & System Availability \\
\hline & 2 & Speed of Response & & 2 & Accessibility \\
\hline & 3 & $\begin{array}{l}\text { fulfillment ( Completion Of } \\
\text { Service) }\end{array}$ & & 3 & Functionality \\
\hline & 4 & Prompt Delivery & & 4 & Efficiency \\
\hline & 5 & Assurance & & 5 & Infrastructure \\
\hline & & & & 6 & Accountability \\
\hline
\end{tabular}




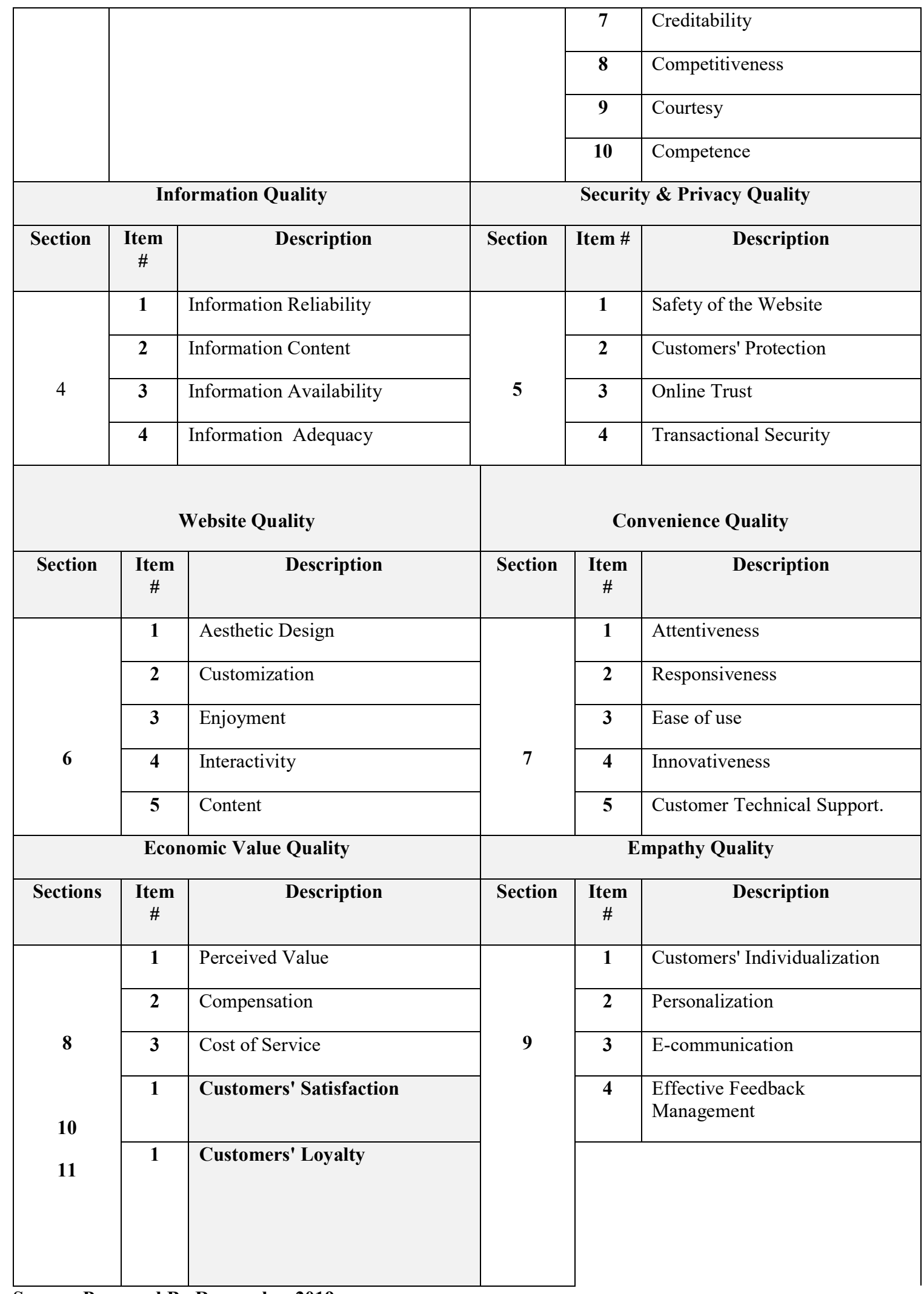

Source: Prepared By Researcher 2019 
11.4(b). Secondary Data: Secondary information includes all sources that searched the topic on e-service qualities and online shopping. Such sources include publications, periodicals, essays, reviews, drafts, standard reports prepared by dependent and independent agencies, evaluation reports and other relevant documentaries.

\subsection{Validity and Reliability of the Instrument}

According to common research principles and practices, an instrument is considered valid if it measures what it is intended to measure and accurately achieves the purpose for which it was designed. To ensure validity of the instrument, face, and content; the questionnaire was given to professionals, experts, scholars and some of online customers for judgment, appropriateness and over all evaluation. Reliability, on the other hand relates to the consistency of collected information. In order to maintain the reliability of the instrument used a pre-test was conducted with a sample size of sixty (60) online Jordanian customers. The responses of respondents were scored and the result of the reliability test was 0.828 showing that the instrument used in this study is regarded as sound, consistent and reliable.

\subsection{Data Collection}

The total number of questionnaires distributed randomly among online Jordanian customers is 1000 , which accounts to about $10 \%$ of the identified target population of 10000 online customers. The total number of returned questionnaires is 740. Returns were subjected to a careful checking and evaluations. Consequently, 60 questionnaires were excluded and regarded as unsuitable for statistical analyses because they do not meet the set conditions and criteria of answering and filling the questionnaires, therefore, the total number of useable returns is 680 . None response is 260 and it was assumed that the non-respondents were either unwilling to cooperate or simply are not interested in the survey. Summary of distributed, returned, useable, non-responses questionnaires are shown in table (3).

Table (3): Summary of Distributed, Returned, Useable, Non-responses Questionnaires

\begin{tabular}{|c|c|c|c|c|c|c|c|c|c|c|}
\hline Condition & \multicolumn{2}{|c|}{$\begin{array}{c}\text { Distributed } \\
\text { Questionnaires }\end{array}$} & \multicolumn{2}{|c|}{$\begin{array}{c}\text { Returned } \\
\text { Questionnaires }\end{array}$} & \multicolumn{2}{c|}{$\begin{array}{c}\text { Useable } \\
\text { Questionnaires }\end{array}$} & \multicolumn{2}{c|}{$\begin{array}{c}\text { Un- Useable } \\
\text { Questionnaires }\end{array}$} & \multicolumn{2}{|c|}{ Non -Response } \\
\hline $\begin{array}{c}\text { Number of } \\
\begin{array}{c}\text { Online } \\
\text { Customers }\end{array}\end{array}$ & Number & $\%$ & Number & $\%$ & Number & $\%$ & Number & $\%$ & Number & $\%$ \\
\cline { 2 - 25 } & 1000 & 100 & 740 & 74 & 680 & 68 & 60 & 7 & 260 & 26 \\
\hline
\end{tabular}

\section{Source: Prepared By Researcher 2019}

\subsection{Procedures}

The needed empirical data for the study were collected through a well-structured questionnaire (with 44 items), which was distributed randomly among online Jordanian customers which represents all regions of Jordan. Simple instructions, guidance and assistance were given on how to correctly read, understand and fill in the questionnaires. Confidentiality of information is assured. The scoring of responses is carried out as follows:

Section (1): No scores were attached (i.e. bio- data)

Sections (2-11): Contain both independent and dependent variables. Respondents were required to provide their rating on their perception using five point Likert's scale (5-Strongly Agree, 4-Agree, 3-Undecided, 2- Disagree, 1Strongly Disagree). This scale best describes the extent to which the respondents agree with each items in the questionnaire. The mean rating of response to questionnaire items is shown in table (4).

Table (4): Mean Rating of responses to questionnaire items

\begin{tabular}{|l|c|c|c|}
\hline \multicolumn{1}{|c|}{ Response Category } & Abbreviation & Points & Bounding Unit \\
\hline Strongly Agree & (SA) & 5 & $4.60-5.00$ \\
\hline Agree & (AG) & 4 & $3.60-4.59$ \\
\hline Undecided & (UN) & 2 & $2.60-3.59$ \\
\hline Disagree & (DI) & 1 & $1.60-2.59$ \\
\hline Strongly Disagree & (SD) & & $1.00-1.59$ \\
\hline
\end{tabular}

Source: Prepared By Researcher 2019 


\section{DATA ANALYSIS \& MAIN FINDINGS}

In order to ensure completeness and logical consistency of responses, data editing was carried out each day by the researcher. Identified mistakes and data gaps were rectified as soon as possible. Once editing was done with, the data were analyzed using quantitative techniques. Data analysis was done using Statistical Package for Social Sciences (SPSS Version16). The use of this package is made with the intension to produce both descriptive and inferential Statistics. The summary of result was presented using frequency distribution and percentages, which was used to determine the proportion of respondents choosing the various responses. Tables, charts and graphs can be used to ensure easy understanding of the analyses. Inferential Statistics such as Pearson Correlation, and Linear Regression statistical model were used to identify and evaluate the causal relationship between dependent and independent variables and to test the hypotheses of the study.

\subsection{Respondents Demographic Profile}

Table (5): Frequency Distribution for Respondents Demographics

\begin{tabular}{|c|c|c|c|c|c|}
\hline Sequence & Demographic items & Frequency & Percent & $\begin{array}{c}\text { Valid } \\
\text { Percent }\end{array}$ & Cumulative \% \\
\hline \multirow[t]{3}{*}{1} & \multicolumn{5}{|l|}{ Gender } \\
\hline & Male & 408 & 60.00 & 60.00 & 60.00 \\
\hline & Female & 272 & 40.00 & 40.00 & 100 \\
\hline \multirow{6}{*}{2} & \multicolumn{5}{|l|}{ Age } \\
\hline & less than 20 Years & 108 & 15.88 & 15.88 & 15.88 \\
\hline & 20-30 Years & 264 & 38.82 & 38.82 & 54.70 \\
\hline & $30-40$ Years & 148 & 21.76 & 21.76 & 76.46 \\
\hline & 40-50 Years & 125 & 18.38 & 18.38 & 94.92 \\
\hline & More than 50 Years & 35 & 05.08 & 05.08 & 100 \\
\hline \multirow{7}{*}{3} & Education Level & & & & \\
\hline & High School & 61 & 08.97 & 08.97 & 08.97 \\
\hline & Bachelor & 172 & 25.29 & 25.29 & 34.26 \\
\hline & Diploma & 165 & 24.26 & 24.26 & 58.52 \\
\hline & H. Diploma & 112 & 16.47 & 16.47 & 74.99 \\
\hline & Post graduate & 102 & 15.00 & 15.00 & 89.99 \\
\hline & Professional Degrees & 68 & 10.01 & 10.01 & 100 \\
\hline \multirow{7}{*}{4} & Occupation Status & & & & \\
\hline & Government Service & 126 & 18.52 & 18.52 & 18.52 \\
\hline & Private Service & 196 & 28.82 & 28.82 & 47.34 \\
\hline & Day laborer & 100 & 14.70 & 14.70 & 62.04 \\
\hline & Students & 102 & 15.00 & 15.00 & 77.04 \\
\hline & House Wives & 107 & 15.73 & 15.73 & 92.77 \\
\hline & Others & 49 & 07.23 & 07.23 & 100 \\
\hline \multirow{5}{*}{5} & Residential Area & & & & \\
\hline & Urban Area & 210 & 30.88 & 30.88 & 30.88 \\
\hline & Sub Urban Area & 185 & 27.20 & 27.20 & 58.08 \\
\hline & Rural Area & 160 & 23.52 & 23.52 & 81.60 \\
\hline & Others & 125 & 18.40 & 18.40 & 100 \\
\hline \multirow{7}{*}{6} & Annual Income (JD) & & & & \\
\hline & Below 3000 & 98 & 14.41 & 14.41 & 14.41 \\
\hline & 3000 to 4999 & 156 & 22.94 & 22.94 & 37.35 \\
\hline & 5000 to 6999 & 144 & 21.17 & 21.17 & 58.52 \\
\hline & 7000 to 8999 & 129 & 18.77 & 18.77 & 77.49 \\
\hline & 8000 to 9999 & 80 & 11.76 & 11.76 & 89.25 \\
\hline & More than 10000 & 73 & 10.75 & 10.75 & 100 \\
\hline 7 & $\begin{array}{c}\text { Computer Literacy } \\
\text { level }\end{array}$ & & & & \\
\hline
\end{tabular}




\begin{tabular}{|c|c|c|c|c|c|}
\hline & Professional Level & 112 & 16.47 & 16.47 & 16.47 \\
\hline & Advanced Level & 166 & 24.41 & 16.47 & 40.88 \\
\hline & Intermediate Level & 181 & 26.61 & 26.61 & 67.49 \\
\hline & Moderate Level & 146 & 21.47 & 21.47 & 88.96 \\
\hline & Beginners Level & 75 & 11.24 & 11.24 & 100 \\
\hline \multirow[t]{6}{*}{8} & Internet Accessibility & & & & \\
\hline & Home & 296 & 43.52 & 43.52 & 43.52 \\
\hline & Office & 86 & 12.64 & 12.64 & 56.16 \\
\hline & Internet Cafe & 134 & 19.70 & 19.70 & 75.86 \\
\hline & Router & 106 & 15.58 & 15.58 & 91.44 \\
\hline & Wireless & 58 & 08.56 & 08.56 & 100 \\
\hline \multirow{5}{*}{9} & Internet Usage (weekly) & & & & \\
\hline & Less Than 7 hours & 55 & 08.08 & 08.08 & 08.08 \\
\hline & 7 hours to 14 hours & 138 & 20.29 & 20.29 & 28.37 \\
\hline & 15 hours to 21 hours & 175 & 25.74 & 25.74 & 54.11 \\
\hline & More than 21 hours & 312 & 45.89 & 45.89 & 100 \\
\hline \multirow{5}{*}{10} & $\begin{array}{l}\text { Online Shopping } \\
\text { Experience }\end{array}$ & & & & \\
\hline & Less Than 1 Year & 143 & 21.30 & 21.30 & 21.30 \\
\hline & 1 year to 2 years & 177 & 26.03 & 26.03 & 47.06 \\
\hline & 3 years to 4 years & 218 & 32.06 & 32.06 & 79.12 \\
\hline & More than 4 years & 142 & 20.88 & 20.88 & 100 \\
\hline & Total & 680 & 100 & 100 & 100 \\
\hline
\end{tabular}

Table 5 above gives the following statistical demographic indications:

\section{1) With respect to Gender:}

Table 5 indicates that the total representation of male respondents among online Jordanian customers is $408(60 \%)$ and female total representation is $272(40 \%)$. The logical explanation for this tendency is that, the employment rate is higher among male online Jordanian customers as compared to females' employment. The reflection of this on results shows that both males and females have increased tendency to do their shopping online. Nevertheless, males have an edge over female online customers in that, males have the responsibility of allocating incomes a cross their various needs which in turn tend to spare more money for online shopping.

\section{2) With respect to Age:}

Table 5 indicates that young aged groups up to the age of 40 years (76.46) are the dominant online buyers. The logical explanation for this tendency is that, the majority of Jordan's population fall within the young category. Such group perceive online shopping as modern, style, easy and affordable compared to conventional or traditional shopping.

\section{3) With respect to Educational Level:}

Table 5 indicates that the dominant respondent groups are holders of higher education degrees and in particular hold bachelor degrees 172(25.29). The logical explanation for this tendency is that, the majority of Jordan's population are highly literate and highly educated. Such group tend to be exposed to modern technologies, which enables them to do their shopping online.

\section{4) With respect to Occupation Status:}

Table 5 indicates that the dominant respondent groups are private sector employees 196(28.82). The logical explanation for this tendency is that, government sector employment is no longer attractive to career searchers. In addition, income in private sector employment is slightly higher compared to public sector. In general, higher income groups tend to make more allowance for online shopping.

\section{5) With respect to Residential Area:}

Table 5 indicates that the dominant respondent groups are residents in Urban area 210(30.88). The logical explanation for this tendency is that most population of Jordan have benefited from cities development and modernization and tend to live in bigger cities. Crowding and time constraints of living in big cities set good ground for online shopping.

6) With respect to Annual Income : 
Table 5 indicates that the dominant respondent groups $156(22.94)$ earn about 3000 to 4999 JD per year and high income earners are the least in numbers with representation of 73(10.75). Income distribution given is a fair reflection of the state of economy that currently prevails in Jordan. Research findings shows that as level of income increases then standard of living improves and consequently people tend to experience noticeable changes in their shopping behavior and habits; therefore, tend to shop online.

\section{With respect to Computer Literacy Level :}

Table 5 indicates that the dominant respondent groups have intermediate computer literacy level 181(26.61). The logical explanation for this tendency is that most population of Jordan have recently experienced computer ownership and hence have intermediate skills in it. Availability of personal computers motivated more people to get involved in online shopping.

\section{7) With respect to Internet Accessibility:}

Table 5 indicates that the dominant respondent groups have internet at home 296(43.52). High accessibility of internet at low cost encouraged more people to navigate various websites for better offers or dealings as compared to conventional methods of shopping.

8) With respect to (weekly) Internet Usage:

Table 5 indicates that the dominant respondent groups spend more than 21 hours 312(45.89) per week on internet. The logical explanation for this tendency is that the majority of population of Jordan are young and consider using the internet as youngish and stylish daily activity. Besides that, high accessibility of internet at low cost encouraged people to stay tuned to the internet for more social media contacts and doing shopping around websites.

\section{9) With respect to Online Shopping Experience :}

Table 5 indicates that the dominant respondent groups have considerable experience in shopping around various websites 3 to 4 years 218(32.06). The logical explanations for this tendency is that a good proportion of the population of Jordan have experienced a good increase in their income; high accessibility of internet at low cost; better internet offers or dealings and changes in shopping behavior and habits; therefore tend to shop online.

The statistical demographic indications mentioned above provide solid lines on how online shopping is perceived in the e-environment. There is a positive customer's perception towards online shopping. This finding is highly supported by the empirical findings of recent research studies like (Ranjbarian et al., 2012), (Astuti et al., 2013) and (Madad et al., 2017).

\subsection{Reliability Analyses}

This part presents the background information of the respondents; findings of the analysis are based on the objectives of the study that identifies the impact of the independent variables such as: customer service quality, system quality, information quality, security \&privacy quality, website quality, convenience quality, economic value quality and empathy quality on the dependent variables that include customers satisfaction and customers loyalty. The study targeted a sample size of 1000 respondents and from which 680 questionnaires were considered as relevant for statistical analysis reaching a response rate of $68 \%$. This response rate was satisfactory to make conclusions on the effect of customer service quality, system quality, information quality, security \&privacy quality, website quality, convenience quality, economic value quality and empathy quality on customer's satisfaction and customer's loyalty. After that, the responses of respondents were scored and the reliability of the tool was determined using Cronbach's Alpha. Accordingly, when reliability values of questionnaire items are more than alpha value then it indicate that the scale can be considered consistent, sound and reliable. For the sake of internal consistency, soundness and reliability, SPSS (version 16) was used to carry out reliability analysis. Cronbach's Alpha reliability analysis are shown in Table (6).

Table (6): Reliability Analysis

\begin{tabular}{|c|l|c|c|}
\hline SN & \multicolumn{1}{|c|}{ Constructs } & Number of items & Cronbach's Alpha \\
\hline 1 & Customer Service Quality & 05 & 0.860 \\
\hline 2 & System Quality & 10 & 0.882 \\
\hline 3 & Information Quality & 06 & 0.872 \\
\hline 4 & Security \&Privacy Quality & 04 & 0.880 \\
\hline 5 & Website Quality & 05 & 0.862 \\
\hline 6 & Convenience Quality & 05 & 0.864 \\
\hline 7 & Economic Value Quality & 03 & 0.869 \\
\hline 8 & Empathy Quality & 04 & 0.882 \\
\hline 9 & Customers Satisfaction & 01 & 0.890 \\
\hline 10 & Customers Loyalty & 01 & 0,856 \\
\hline 11 & The entire Questionnaire & 44 & 0.864 \\
\hline
\end{tabular}


In general, higher alpha values shows a more reliable generated scale. According to (Cooper and Shindler, 2007) 0.70 is an acceptable reliability coefficient. In table (6), the reliability values of the stated variables ( ranges from 0.856 to 0.890$)$ are greater than the prescribed threshold value of ( $\propto=0.70)$ and in comparison Cronbach's Alpha values are compatible to reliability test of the conducted pilot study with Cronbach's Alpha value $(\propto=0.828)$; hence, the scale is said to be sound and reliable.

\subsection{Validity Analyses}

Factor analysis were carried out before inferential analysis of the results on customer service quality, system quality, information quality, security \&privacy quality, website quality, convenience quality, economic value quality and empathy quality as the independent variables and customers satisfaction and customers loyalty as the dependent variables. The purpose of such analysis is to describe variability between the observed theme and check for any correlated variables with the aim of reducing data that was found redundant. For the forty four items analyzed as shown on table 7 all items scored more than 0.3 which is the minimum requirement for inclusion of variables into the final model as recommended by (Hair et al.,2010). In line with this recommendation, any item not scoring above 0.3 should be dropped from the model and not further analyzed. By application, no item was declared redundant and therefore all items retained in the model and were further analyzed. Factor analysis are shown in table (7).

Table (7): Factor Analysis on customer service quality, system quality, information quality, security \&privacy quality, website quality, convenience quality, economic value quality and empathy quality on customer's satisfaction and customer's loyalty

\begin{tabular}{|c|c|c|c|c|}
\hline \multirow{2}{*}{$\begin{array}{c}\text { Items } \\
\text { No }\end{array}$} & \multicolumn{4}{|c|}{ Variables Measures } \\
\hline & $\begin{array}{c}\text { Customer Service } \\
\text { Quality } \\
\text { Measures }\end{array}$ & $\begin{array}{c}\text { System Quality } \\
\text { Measures }\end{array}$ & $\begin{array}{c}\text { Information } \\
\text { Quality } \\
\text { Measures }\end{array}$ & $\begin{array}{c}\text { Security\&Privacy } \\
\text { Quality } \\
\text { Measures }\end{array}$ \\
\hline 1 & 0.840 & 0.811 & 0.851 & 0.831 \\
\hline 2 & 0.820 & 0.830 & 0.823 & 0.850 \\
\hline 3 & 0.810 & 0.840 & 0.838 & 0.845 \\
\hline 4 & 0.830 & 0.830 & 0.833 & 0.844 \\
\hline 5 & 0.810 & 0.810 & 0.810 & -- \\
\hline 6 & -- & 0.819 & 0.830 & -- \\
\hline 7 & -- & 0.820 & -- & -- \\
\hline 8 & -- & 0.820 & -- & -- \\
\hline 9 & -- & 0.800 & -- & -- \\
\hline 10 & -- & 0.812 & -- & -- \\
\hline \multirow{2}{*}{$\begin{array}{c}\text { Items } \\
\text { No }\end{array}$} & \multicolumn{4}{|c|}{ Variables Measures } \\
\hline & $\begin{array}{l}\text { Website } \\
\text { Quality }\end{array}$ & $\begin{array}{l}\text { Convenience } \\
\text { Quality }\end{array}$ & $\begin{array}{c}\text { Economic Value } \\
\text { Quality }\end{array}$ & $\begin{array}{l}\text { Empathy } \\
\text { Quality }\end{array}$ \\
\hline 1 & 0.850 & 0.860 & 0.820 & 0.841 \\
\hline 2 & 0.835 & 0.825 & 0.834 & 0.840 \\
\hline 3 & 0.822 & 0.862 & 0.832 & 0.865 \\
\hline 4 & 0.830 & 0.837 & & 0.824 \\
\hline 5 & 0.819 & 0.849 & & \\
\hline \multirow{2}{*}{$\begin{array}{c}\text { Items } \\
\text { No }\end{array}$} & \multicolumn{4}{|c|}{ Variables Measures } \\
\hline & $\begin{array}{c}\text { Customers } \\
\text { Satisfaction }\end{array}$ & $\begin{array}{l}\text { Customers } \\
\text { Loyalty }\end{array}$ & -- & -- \\
\hline 1 & 0847 & 0839 & -- & -- \\
\hline
\end{tabular}

\subsection{Descriptive Statistics}

Descriptive Statistics in the forms of means and standard deviations for all variables and responses were computed. The computed means signifies levels of agreeableness and disagreeableness of the respondents. Whereas the values of standard deviations serve as fundamental measures of variability. Computations of means and standard deviations are shown in table (8). 
Table (8): Rates of on Customer Service Quality, System Quality, Information Quality, Security \&Privacy Quality, Website Quality, Convenience Quality, Economic Value Quality and Empathy Quality on Customers Satisfaction and Customers Loyalty

\begin{tabular}{|c|c|c|c|c|c|c|c|}
\hline \multicolumn{4}{|c|}{ Customer Service Quality } & \multicolumn{4}{|c|}{ System Quality } \\
\hline Section & Description & Mean & SD & Section & Description & Mean & SD \\
\hline \multirow{10}{*}{2} & Initial Contact & 4.02 & 0.74 & \multirow{10}{*}{3} & System Availability & 4.12 & 0.76 \\
\hline & Speed of Response & 4.13 & 0.78 & & Accessibility & 4.04 & 0.73 \\
\hline & $\begin{array}{l}\text { Fulfillment } \\
\text { ( Completion Of Service) }\end{array}$ & 4.52 & 0.81 & & Functionality & 4.53 & 0.82 \\
\hline & Prompt Delivery & 4.69 & 0.83 & & Efficiency & 4.18 & 0.77 \\
\hline & Assurance & 3.98 & 0.72 & & Infrastructure & 3.99 & 0.72 \\
\hline & & & & & Accountability & 3.97 & 0.71 \\
\hline & & & & & Creditability & 3.65 & 0.73 \\
\hline & & & & & Competitiveness & 4.07 & 0.77 \\
\hline & & & & & Courtesy & 4.11 & 0,75 \\
\hline & & & & & Competence & 4. 02 & 0.78 \\
\hline \multicolumn{4}{|c|}{ Information Quality } & \multicolumn{4}{|c|}{ Security \& Privacy Quality } \\
\hline Section & Description & Mean & SD & Section & Description & Mean & SD \\
\hline \multirow{6}{*}{4} & Information Reliability & 4.79 & 0.84 & \multirow{6}{*}{5} & Safety of the Website & 4.89 & 0.86 \\
\hline & Information Content & 4.01 & 0.74 & & Customers' Protection & 4.25 & 0.79 \\
\hline & Information Availability & 4.19 & 0.76 & & Online Trust & 3.99 & 0.78 \\
\hline & Information Adequacy & 4.37 & 0.79 & & Transactional Security & 3.97 & 0.76 \\
\hline & Information Honesty & 4.32 & 0.80 & & & & \\
\hline & Trustworthiness & 4.59 & 0.82 & & & & \\
\hline \multicolumn{4}{|c|}{ Website Quality } & \multicolumn{4}{|c|}{ Convenience Quality } \\
\hline \multirow[t]{4}{*}{ Section } & Description & Mean & SD & Section & Description & Mean & SD \\
\hline & Aesthetic Design & 4.01 & 0.73 & & Attentiveness & 4.72 & 0.81 \\
\hline & Customization & 4.43 & 0.81 & & Responsiveness & 4.63 & 0.83 \\
\hline & Enjoyment & 4.65 & 0.79 & & Ease of use & 4.23 & 0.75 \\
\hline
\end{tabular}




\begin{tabular}{|c|c|c|c|c|c|c|c|}
\hline \multirow[t]{2}{*}{6} & Interactivity & 4.17 & 0.76 & \multirow[t]{2}{*}{7} & Innovativeness & 4.33 & 0.74 \\
\hline & Content & 4.14 & 0.71 & & $\begin{array}{l}\text { Customer Technical } \\
\text { Support. }\end{array}$ & 4.12 & 0.73 \\
\hline \multicolumn{4}{|c|}{ Economic Value Quality } & \multicolumn{4}{|c|}{ Empathy Quality } \\
\hline Section & Description & Mean & SD & Section & Description & Mean & SD \\
\hline \multirow{4}{*}{8} & Perceived Value & 4.11 & 0.76 & \multirow{4}{*}{9} & $\begin{array}{l}\text { Customers' } \\
\text { Individualization }\end{array}$ & 4.01 & 0.71 \\
\hline & Compensation & 4.23 & 0.78 & & Personalization & 4.32 & 0.81 \\
\hline & Cost of Service & 4.68 & 0.83 & & E-communication & 4.19 & 0.78 \\
\hline & & & & & $\begin{array}{l}\text { Effective Feedback } \\
\text { Management }\end{array}$ & 4.07 & 0.74 \\
\hline \multicolumn{4}{|c|}{ Customers Satisfaction } & \multicolumn{4}{|c|}{ Customers Loyalty } \\
\hline Section & Description & Mean & SD & Section & Description & Mean & SD \\
\hline 10 & $\begin{array}{l}\text { Customers } \\
\text { Satisfaction }\end{array}$ & 4.12 & 0.79 & 11 & $\begin{array}{l}\text { Customers } \\
\text { Loyalty }\end{array}$ & 4.09 & 0.76 \\
\hline
\end{tabular}

Table(8) shows all ranking of respondent's answers concerning the impact of customer service quality, system quality, information quality, security \&privacy quality, website quality, convenience quality, economic value quality and empathy quality as the independent variables and customers satisfaction and customers loyalty as the dependent variables. The" independent variable "customer service quality" has means that ranges from (3.98-4.69) and standard deviation that ranges from $(0.72-0.83)$. These statistics show that most respondents agree on the statement that customer service quality has impact on customer's satisfaction and customer's loyalty. The independent variable "system quality" has means that ranges from (3.65-4.53) and standard deviation that ranges from (0.71-0.82). These statistics show that most respondents agree on the statement that system quality has impact on customer's satisfaction and customer's loyalty. The independent variable "information quality" has means that ranges from (4.01-4.79) and standard deviation that ranges from (0.74-0.84). These statistics show that most respondents agree on the statement that information quality has impact on customer's satisfaction and customer's loyalty. The independent variable "security \&privacy quality" has mean that ranges from (3.97-4.89) and standard deviation that ranges from (0.76-0.86). These statistics show that most respondents agree on the statement that security \& privacy quality has impact on customer's satisfaction and customer's loyalty. The independent variable "website quality" has means that ranges from (4.01-4.65) and standard deviation that ranges from (0.71-0.81). These statistics show that most respondents agree on the statement that website quality has impact on customer's satisfaction and customer's loyalty. The independent variable "convenience quality" has means that ranges from (4.12-4.72) and standard deviation that ranges from $(0.73-0.83)$. These statistics show that most respondents agree on the statement that convenience quality has impact on customer's satisfaction and customer's loyalty.

The independent variable "economic value quality" has means that ranges from (4.11-4.68) and standard deviation that ranges from $(0.76-0.83)$. These statistics show that most respondents agree on the statement that economic value quality has impact on customer's satisfaction and customer's loyalty. The independent variable "empathy quality" has means that ranges from (4.01-4.32) and standard deviation that ranges from (0.71-0.81). These statistics show that most respondents agree on the statement that empathy quality has impact on customer's satisfaction and customer's loyalty. The dependent variable "customer satisfaction" has a mean of (4.35) and a standard deviation of (0.79). These statistics show that most respondents agree on the statement that customer satisfaction is highly influenced by all independent variables mentioned in the study. Finally, the dependent variable "customer loyalty" has a mean of (4.18) and a standard deviation of (0.76). These statistics show that most 
respondents agree on the statement that customer's satisfaction is influenced by all independent variables mentioned in the study and customer's loyalty is influenced by customer's satisfaction

Descriptive Statistics in the form of overall means and overall standard deviations for the independent and dependent variables for respondents were computed and presented in table(8).

Table (9): Over all means and standard deviations for Customer Service Quality, System Quality, Information Quality, Security \&Privacy Quality, Website Quality, Convenience Quality, Economic Value Quality and Empathy Quality on Customers Satisfaction and Customers Loyalty_Satisfaction and Customers Loyalty

\begin{tabular}{lcc}
\hline \multicolumn{1}{c}{ Variables } & Means & Standard Deviations \\
& & \\
\hline Customer Service Quality & 4.298 & 0.776 \\
System Quality & 4.080 & 0.745 \\
Information Quality & 4.379 & 0.788 \\
Security \&Privacy Quality & 4.247 & 0.765 \\
Website Quality & 4.236 & 0.758 \\
Convenience Quality & 4.314 & 0.761 \\
Economic Value Quality & 4.356 & 0.774 \\
Empathy Quality & 4.182 & 0.760 \\
Customers Satisfaction & 4.120 & 0.790 \\
Customers Loyalty & 4.090 & 0.762 \\
\hline
\end{tabular}

Table (9) above shows that the overall means for all variables ranged from a low value of 4.080 a high value of 4.379. Results of descriptive statistics reveal that the impact of customer service quality, system quality, information quality, security \&privacy quality, website quality, convenience quality, economic value quality and empathy quality on customer's satisfaction and customer's loyalty is considerable.

Table (9) reveals that, the means for all independent variables are relatively high, and are above the mean value of first dependent variable (customer's satisfaction). Expressed in figures 4.298, 4.080, 4.379 , 4.247, 4.236, 4.314, 4.356 , and $4.182>4.120$; this indicates that customer's satisfaction is influenced by customer service quality, system quality, information quality, security \&privacy quality, website quality, convenience quality, economic value quality and empathy quality. The same statement is true for the second dependent variable. The means for all independent variables customer service quality, system quality, information quality, security \&privacy quality, website quality, convenience quality, economic value quality and empathy quality are relatively high, and are a above the overall mean value of second dependent variable (customer's loyalty); expressed in figures 4.298, 4.080, $4.379,4.247,4.236,4.314,4.356$, and $4.182>4.090$ this indicates, that customer's loyalty is influenced by customer service quality, system quality, information quality, security \&privacy quality, website quality, convenience quality, economic value quality, empathy quality and customers satisfaction.

\subsection{Inferential Statistics}

\section{5 (a). Pearson Correlation Coefficients}

Pearson's correlation coefficient ( $\mathrm{r}$ ) is a measure of the strength of the association between set of variables. Research studies normally include several variables; beyond knowing the means and standard deviations of the dependent and independent variables, the researcher would often like to know how one variable relates to another. Statistically, correlation ranges between -1.0 and +1.0 . Furthermore, the researcher needs to know if correlation exists between variables is significant or not (i.e.; if it has occurred solely by chance or if there is a high probability of its actual existence). In social sciences research both significance levels of $p=0.01$ and $p=0.05$ are generally accepted conventional levels. This indicates that 99 and 95 times out of 100, the researcher can be sure that there is a true or significant correlation between the variables and there is only $1 \%$ or $5 \%$ chances that the relationship does not truly exist. The correlation matrix between dependent and independent variables are exhibited in table (10). 
Iㅏ영

\begin{tabular}{|c|c|c|c|c|c|c|c|c|c|c|}
\hline \multicolumn{11}{|c|}{ Table (10): Correlation Matrix for all variables involved * } \\
\hline $\begin{array}{c}\text { Variables } \\
\text { Coding }\end{array}$ & 1 & 2 & 3 & 4 & 5 & 6 & 7 & 8 & 9 & 10 \\
\hline 1 & 1.000 & & & & & & & & & \\
\hline 2 & 0.668 & 1.000 & & & & & & & & \\
\hline 3 & 0.642 & 0.634 & 1.000 & & & & & & & \\
\hline 4 & 0.626 & 0.603 & 0.621 & 1.000 & & & & & & \\
\hline 5 & 0.597 & 0.599 & 0.596 & 0.633 & 1.000 & & & & & \\
\hline 6 & 0.588 & 0.606 & 0.613 & 0.609 & 0.618 & 1.000 & & & & \\
\hline 7 & 0.611 & 0.632 & 0.622 & 0.637 & 0.625 & 0.596 & 1.000 & & & \\
\hline 8 & 0.652 & 0.631 & 0.614 & 0.620 & 0.648 & 0.618 & 0.645 & 1.000 & & \\
\hline 9 & 0.603 & 0.612 & 0.622 & 0.637 & 0.637 & 0.589 & 0.593 & 0.626 & 1.000 & \\
\hline 10 & 0.592 & 0.602 & 0.614 & 0.628 & 0.622 & 0.578 & 0.566 & 0.578 & 0.589 & 1.000 \\
\hline
\end{tabular}

*Note: Coding of Variables include:

(1= Customers Satisfaction, 2=Customers Loyalty, 3=Customer Service Quality, 4=System Quality, 5= Information Quality, 6= Security \&Privacy Quality, 7= Website Quality, 8= Convenience Quality, 9= Economic Value Quality, 10= Empathy Quality)

Table 10 above depicted positive correlation between the independent variables and the dependent variables referred to in this study. Results indicate that, correlation exists between customer service quality, system quality, information quality, security \&privacy quality, website quality, convenience quality, economic value quality and empathy quality and customer's satisfaction and customer's loyalty. Correlation range is between 0.688 to 0.588 . Highest to lowest positive correlation in this study were depicted between customer service quality, system quality, information quality, security and privacy quality, website quality, convenience quality, economic value quality and empathy quality and customers satisfaction. (In numbers $r=0.688,0.652,0.642,0.626,0.611,0.603,0.597$, $0.592,0.588, \mathrm{p}<0.01)$. In other words, the results indicate that all these variables have significant correlation with customer's satisfaction. In addition, there exists correlation between customer service quality, system quality, information quality, security \&privacy quality, website quality, convenience quality, economic value quality and empathy quality and customers loyalty. Correlation range is 0.634 to 0.599 . Highest to lowest positive correlation in this study were depicted between customer service quality, system quality, information quality, security \&privacy quality, website quality, convenience quality, economic value quality and empathy quality and customers loyalty ( In numbers $r=0.634,0.632,0.631,0.612,0.606,0.603,0.602,0.599 \mathrm{p}<0.01$ ). In other words, the results indicate that all these variables have significant correlation with customer's loyalty.

Table (11): Coefficients for Customer Service Quality, System Quality, Information Quality, Security \&Privacy Quality, Website Quality, Convenience Quality, Economic Value Quality and Empathy Quality on Customers Satisfaction

\begin{tabular}{|c|c|c|c|c|c|}
\hline \multirow[t]{2}{*}{ Variables } & \multicolumn{2}{|c|}{$\begin{array}{c}\text { Unstandardized } \\
\text { Coefficients }\end{array}$} & \multirow{2}{*}{$\begin{array}{c}\begin{array}{c}\text { Standardized } \\
\text { Coefficients }\end{array} \\
\text { Beta }\end{array}$} & \multirow[t]{2}{*}{$\underline{t}$} & \multirow[t]{2}{*}{ Sig. } \\
\hline & Beta & Std. Error & & & \\
\hline Constant & 0.342 & 0.043 & 0.492 & 3.166 & 0.006 \\
\hline Customer Service Quality & 0.532 & 0.039 & 0.526 & 4.283 & 0.033 \\
\hline System Quality & 0.511 & 0.041 & 0.504 & 4.122 & 0.041 \\
\hline Information Quality & 0.493 & 0.040 & 0.506 & 4.144 & 0.031 \\
\hline Security \& Privacy Quality & 0.488 & 0.042 & 0.473 & 3.821 & 0.040 \\
\hline Website Quality & 0.511 & 0.039 & 0,513 & 4.208 & 0.042 \\
\hline Convenience Quality & 0.544 & 0.041 & 0.510 & 4.187 & 0.046 \\
\hline Economic Value Quality & 0.499 & 0.041 & 0.503 & 4.110 & 0.042 \\
\hline Empathy Quality & 0.418 & 0.042 & 0.468 & 3.917 & 0.029 \\
\hline
\end{tabular}

Table 11 above shows the exact relationship between customer service quality, system quality, information quality, security \&privacy quality, website quality, convenience quality, and economic value quality and empathy quality and customers satisfaction. The results depict that customer's satisfaction is 0.342 . A unit modification in customer service quality would affect customer's satisfaction by 0.532 . A unit improvement in system quality would affect customer's satisfaction by 0.511 . A unit increase in information quality would affect customer's satisfaction by 0.493 . A unit alteration of security \&privacy quality would affect customer's satisfaction by 0.488 . A unit upgrade 
of website quality would affect customer's satisfaction by 0.4511 . A unit change of convenience quality would affect customer's satisfaction by 0.544 . A unit modification of economic value quality would affect customer's satisfaction by 0.499 . Finally, a unit improvement in empathy quality would affect customer's satisfaction by 0.418 . Convenience quality has the greatest impact on customer's satisfaction. While the empathy quality has the lowest impact on customer's satisfaction. At 5\% level of significance and 95\% level of confidence, customer service quality had 0.033 level of significance. System quality had 0.041 level of significance. Information quality had 0.031 level of significance. Security \&privacy quality had 0.040 level of significance. Website quality had 0.042 level of significance. Convenience quality had 0.046 level of significance. Economic value quality had 0.042 level of significance. Finally, Empathy quality had 0.029 level of significance. The above sequence reflects the most significant e-qualities. Hence, all variables found significant and had positive impact on customer's satisfaction.

Table (12): Coefficients for Customer Service Quality, System Quality, Information Quality, Security \&Privacy Quality, Website Quality, Convenience Quality, Economic Value Quality and Empathy Quality on Customer's Loyalty.

\begin{tabular}{|c|c|c|c|c|c|}
\hline \multirow[t]{2}{*}{ Variables } & \multicolumn{2}{|c|}{$\begin{array}{l}\text { Unstandardized } \\
\text { Coefficients }\end{array}$} & \multirow{2}{*}{$\begin{array}{c}\begin{array}{c}\text { Standardized } \\
\text { Coefficients }\end{array} \\
\text { Beta } \\
\end{array}$} & \multirow[t]{2}{*}{$\underline{\mathbf{t}}$} & \multirow[t]{2}{*}{ Sig. } \\
\hline & Beta & Std. Error & & & \\
\hline Constant & 0.329 & 0.042 & 0.463 & 3.128 & 0.004 \\
\hline Customer Service Quality & 0.512 & 0.040 & 0.521 & 4.275 & 0.045 \\
\hline System Quality & 0.502 & 0.044 & 0.509 & 4.172 & 0.032 \\
\hline Information Quality & 0.484 & 0.039 & 0.503 & 4.110 & 0.042 \\
\hline Security \& Privacy Quality & 0.438 & 0.041 & 0.493 & 3.964 & 0.043 \\
\hline Website Quality & 0.427 & 0.042 & 0,507 & 4.166 & 0.041 \\
\hline Convenience Quality & 0.532 & 0.041 & 0.516 & 4.199 & 0.036 \\
\hline Economic Value Quality & 0.501 & 0.039 & 0.511 & 4.183 & 0.044 \\
\hline Empathy Quality & 0.416 & 0.040 & 0.487 & 3.812 & 0.030 \\
\hline
\end{tabular}

Table 12 above shows the exact relationship between customer service quality, system quality, information quality, security \&privacy quality, website quality, convenience quality, and economic value quality and empathy quality and customers loyalty. The results depict that customer's loyalty is 0.329 . A unit modification in customer service quality would affect customer's loyalty by 0.512 . A unit improvement in system quality would affect customer's loyalty by 0.502 . A unit increase in information quality would affect customer's loyalty by 0.484 . A unit alteration of security \&privacy quality would affect customer's loyalty by 0.438 . A unit upgrade of website quality would affect customer's loyalty by 0.427 . A unit change of convenience quality would affect customer's loyalty by 0.532 . A unit modification of economic value quality would affect customer's loyalty by 0.532 . Finally, a unit improvement in empathy quality would affect customer's loyalty by 0.416 . Convenience quality has the greatest impact on customer's loyalty. While the empathy quality has the lowest impact on customer's loyalty. At 5\% level of significance and 95\% level of confidence, customer service quality had 0.045 level of significance. System quality had 0.032 level of significance. Information quality had 0.042 level of significance. Security \&privacy quality had 0.043 level of significance. Website quality had 0.041 level of significance. Convenience quality had 0.036 level of significance. Economic value quality had 0.044 level of significance. Finally, Empathy quality had 0.030 level of significance. The above sequence reflects the most significant e-qualities. Hence, all variables found significant and had positive impact on customer's loyalty.

12.5(a). Regression Analysis (Hypothesis Testing)

Regression analysis is a standard statistical procedure used for estimating the strength of relationships amongst the independent and the dependent variables (Lane, 2017). Linear regression model is used for testing the abovementioned hypothesis

12.5.a.1.Customer Service Quality, System Quality, Information Quality, Security \&Privacy Quality, Website Quality, Convenience Quality, Economic Value Quality and Empathy Quality on Customers Satisfaction 
Table (13): Model Summary for Customer Service Quality, System Quality, Information Quality, Security \&Privacy Quality, Website Quality, Convenience Quality, Economic Value Quality and Empathy Quality on Customers Satisfaction

\begin{tabular}{|c|c|c|c|c|c|c|c|c|}
\hline Model. No & $\mathbf{R}$ & $\begin{array}{c}\mathbf{R} \\
\text { Square }\end{array}$ & $\begin{array}{l}\text { Adjusted } \\
\text { R square }\end{array}$ & $\begin{array}{c}\text { Std. } \\
\text { Error }\end{array}$ & $\begin{array}{l}(\beta) \\
\text { Beta } \\
\end{array}$ & F Value & $\begin{array}{c}\text { T } \\
\text { Value } \\
\end{array}$ & $\begin{array}{c}\text { Sig } \\
\text { Levels }\end{array}$ \\
\hline $\begin{array}{c}\text { (1) Customer Service } \\
\text { Quality \& } \\
\text { Customers }\end{array}$ & .651 & .412 & .366 & .941 & .534 & 18.332 & 6.423 & .000 \\
\hline $\begin{array}{l}\text { Satisfaction } \\
\text { (2) System Quality } \\
\text { \& Customers } \\
\text { Satisfaction } \\
\text { (3) Information }\end{array}$ & .632 & .401 & .352 & .936 & .540 & 18. 808 & 6. 129 & .000 \\
\hline $\begin{array}{c}\text { Quality \& Customers } \\
\text { Satisfaction }\end{array}$ & .611 & .356 & .343 & .927 & .498 & 18.108 & 6.182 & .000 \\
\hline $\begin{array}{c}\text { (4) Security and } \\
\text { Privacy Quality \& } \\
\text { Customers } \\
\text { Satisfaction }\end{array}$ & .598 & .342 & .339 & .911 & .438 & 17.667 & 5.867 & .000 \\
\hline $\begin{array}{l}\text { (5) Website Quality } \\
\text { \& Customers } \\
\text { Satisfaction } \\
\text { (6) Convenience }\end{array}$ & .599 & .357 & .347 & .922 & .463 & 17.728 & 5.933 & .000 \\
\hline $\begin{array}{c}\text { Quality \& Customers } \\
\text { Satisfaction }\end{array}$ & .648 & .403 & .359 & .938 & .542 & 18.283 & 4.137 & .000 \\
\hline $\begin{array}{l}\text { (7) Economic Value } \\
\text { Quality \& Customers } \\
\text { Satisfaction }\end{array}$ & .621 & .376 & .337 & .917 & .531 & 18.116 & 6.113 & .000 \\
\hline $\begin{array}{l}\text { (8) Empathy Quality } \\
\text { \& Customers } \\
\text { Satisfaction }\end{array}$ & .582 & .352 & .329 & .902 & .412 & 16.492 & 5.752 & .000 \\
\hline $\begin{array}{l}\text { Note: The beta colum } \\
\text { standard deviation di } \\
\text { deviation (the standar }\end{array}$ & d sce & of the de & $\begin{array}{l}\text { tandardiz } \\
\text { ent varial } \\
\text { lent varial }\end{array}$ & $\begin{array}{l}\text { gressic } \\
\text { ould } 1\end{array}$ & $\begin{array}{l}\text { oeffic } \\
\text { on }\end{array}$ & $\begin{array}{l}\text { t. Beta } r \\
\text { depende }\end{array}$ & $\begin{array}{l}\text { sents } t \\
\text { variabl }\end{array}$ & $\begin{array}{l}\text { ffect tha } \\
\text { standard }\end{array}$ \\
\hline
\end{tabular}

Table 13 has deflected the following regression analysis as per models (1-8):

Models (1-8): The values of $\mathrm{R}$ Square implies that $(41 \%, 40 \%, 35 \%, 34 \%, 35 \%$ and $40 \%, 37 \%, 35 \%)$ variations in the dependent variable customer's satisfaction is because of independent variables influence (customer service quality, system quality, information quality, security \&privacy quality, website quality, convenience quality, economic value quality and empathy quality). The following set of $F$ values $(18.332,18.808,18.108,17.667$, $17.728,18.283,18.116$, and16.492) implies that, the model possess significant overall strength. This ensures the correctness of models (1-8). Based on Beta coefficients the models implies that (customer service quality, system quality, information quality, security \&privacy quality, website quality, convenience quality, economic value quality and empathy quality) cause $(53 \%, 54 \%, 49 \%, 43 \%, 46 \%, 54 \%, 53 \%$ and $41 \%$ ) positive variations in customer's satisfaction and t values $(6.423,6.129,6.182,5.867,5.933,4.137,6.113$ and 5.752 with $\mathrm{p}<0.001)$. So $\mathrm{H} 0 \mathrm{~s}(1-8)$ which declares that "there is no significance impact of customer service quality, system quality, information quality, security and privacy quality, website quality, convenience quality, economic value quality and empathy quality " are rejected and $\mathrm{H} 1 \mathrm{~s}(1-8)$ which declares that "there is a significance impact of customer service quality, system quality, information quality, security \&privacy quality, website quality, convenience quality, economic value quality and empathy quality " are accepted. 
12.5.a.2.Customer Service Quality, System Quality, Information Quality, Security \&Privacy Quality, Website Quality, Convenience Quality, Economic Value Quality and Empathy Quality on Customer's loyalty

Table (14): Model Summary for Customer Service Quality, System Quality, Information Quality, Security \&Privacy Quality, Website Quality, Convenience Quality, Economic Value Quality and Empathy Quality on Customer's loyalty

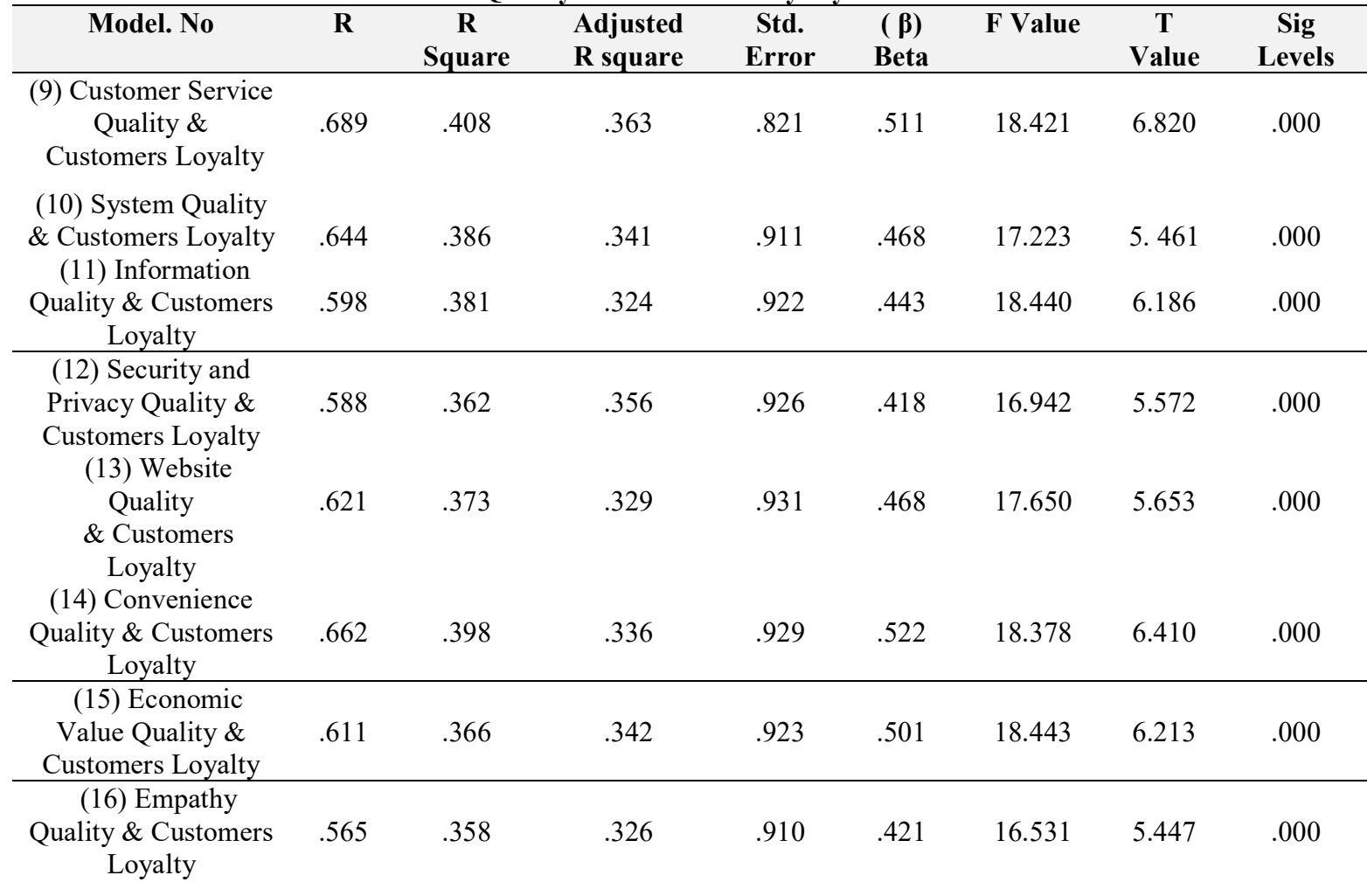

Note: The beta column indicates the value of standardized regression coefficient. Beta represents the effect that standard deviation difference in the independent variable would have on the dependent variable in standard deviation (the standardized scores of the dependent variable).

Table 14 has deflected the following regression analysis as per models (9-16):

Models (9-16): The values of R Square implies that $(40 \%, 38 \%, 38 \%, 36 \%, 37 \%$ and $39 \%, 36 \%, 35 \%$ ) variations in the dependent variable customer's loyalty is because of the independent variables influence (customer service quality, system quality, information quality, security \&privacy quality, website quality, convenience quality, economic value quality and empathy quality). The following set of $\mathrm{F}$ values $(18.421,17.223,18.440,16.942$, $17.650,18.378,18.443$, and16.531) implies that, the model possess significant overall strength. This ensures the correctness of models (9-16). Based on Beta coefficients the models implies that (customer service quality, system quality, information quality, security \&privacy quality, website quality, convenience quality, economic value quality and empathy quality) cause $(51 \%, 46 \%, 44 \%, 41 \%, 46 \%, 52 \%, 50 \%$ and $42 \%$ ) positive variations in customer's loyalty and t values $(6.820,5.461,6.186,5.572,5.653,6.410,6.213$ and 5.447 with p<0.001). So $\mathrm{H} 0 \mathrm{~s}(9-16)$ which declares that "there is no significance impact of customer service quality, system quality, information quality, security and privacy quality, website quality, convenience quality, economic value quality and empathy quality " are rejected and $\mathrm{H} 1 \mathrm{~s}(9-16)$ which declares that "there is a significance impact of customer service quality, system quality, information quality, security \&privacy quality, website quality, convenience quality, economic value quality and empathy quality " are accepted. 


\section{RESEARCH FINDINGS}

\section{3. (1). Discussion of Findings}

The overall purpose of this research was to assess the impact of customer service quality, system quality, information quality, security \&privacy quality, website quality, convenience quality, economic value quality and empathy quality on customer's satisfaction and customer's loyalty. Most of the respondents through their answers confirmed that customer service quality, system quality, information quality, security \&privacy quality, website quality, convenience quality, economic value quality and empathy quality have impact on customer's satisfaction and customer's loyalty. General research on the topic confirmed that most demographic factors are of considerable importance. Such research had shown tendency of respondents to shop online. However, demographic factors weight of importance is not the same for all listed factors especially gender which came parallel to many research that confirmed the unequal presentation of males and females. In line with this is finding is the findings of (Mada et al., 2017) summarized that male respondents were recorded high score as compared to female respondents. Therefore, equal representation of males and female respondents opens more opportunities for future research. Furthermore, findings of recent published research is consistent with current study in that demographic profile plays a significant role in any service sector and online sector is no exception ( Sundaram et al., 2017). Descriptive statistics in the form of means, standard deviation and percentages and cumulative percentages provide evidence that respondent's demographic profile and customer service quality, system quality, information quality, security \&privacy quality, website quality, convenience quality, economic value quality and empathy quality have impact on customer's satisfaction and customer's loyalty. Inferential statistics, on the other hand generated tabulated statistics that shows the results of correlations, coefficients and regressions on the data collected from 680 respondents through valid returned questionnaires. After applying the linear regression on the collected data to check the cause and possible effect of relationship between customer service quality, system quality, information quality, security \&privacy quality, website quality, convenience quality, economic value quality and empathy quality (the independent variables) and customer's satisfaction and customer's loyalty (the dependent variables) the above mentioned results have been drawn. The probability of f-statistic shows the significance level of the research. According to standard practice, if $p$ value is $<0.05$ so then it is significant. In this study the above given tables demonstrates the $p$ value is 0.000 which is $<0.05$ thus the model of the research is statistically significant. Therefore, the independent variables of the study have significant relationship with dependent variables of the study. Finally, the standardized values in the tables above clearly illustrate that listed qualities such as customer service quality, system quality, information quality, security \&privacy quality, website quality, convenience quality, economic value quality have positive impact on customer's satisfaction and customer's loyalty.

Supportive evidence comes from many service quality research papers that studied the impact of service quality dimensions online customers. One of which is (Alam et al., 2008). This research demonstrated that service quality dimensions positively affected the customer's satisfaction and customer's loyalty. Current research findings are consistent to (Chen, 2006) conclusions in that, service qualities and overall customer's satisfaction have positive significant relationship. Further support comes from (Kitapci et al.,2014) empirical findings that service qualities like empathy and reliability play important role in enhancing customers satisfaction in various online service industries. Confirmation to present findings was clearly stated in (Jiyoung et al., 2009). In this study, the results show that website qualities especially website design has strong influence on e- satisfaction. Furthermore, the initial expectation regarding the effect of security and privacy on satisfaction came true. A noticeable support is found in the study of (Ganguli et al., 2011). Their study showed positive significant effect of security and privacy on customer's satisfaction and loyalty. Information quality dimension prevailed in most research studies on online businesses. The present study findings on information quality is no different from other studies. Hence this finding is consistent with (Than and Grandon, 2002) in which they identified a strong customers concern regarding information qualities like availability and handling of information. Consistent with a previous study (Zhu et al., 2002), this study found a positive relationship among overall service quality and customers satisfaction and loyalty. An additional support comes from (DeLone and McLean, 2003); here information quality, system quality, and service quality are the three primary contributors to user satisfaction about information systems. Findings of current study supports previous research (Mustafa, 2011), (Ghane, 2011), (Flavian et al., 2006) in the following aspects: ease of use, information content, customer quality, and transaction and delivery process are factors that have strong influence on online customer's satisfaction. Finding of this study shows strong impact of economic value quality dimensions on customer's satisfaction and customer's loyalty. Elements of economic value quality included fees, costs of service and so on. Prior research (Siriluck and Speece, 2003) has empirically found positive relationship between "fees and costs of service" and customer's satisfaction.

In contrast others studies provided evidence that not all e-service qualities are significant predictors of overall service quality and customer satisfaction. For example (Lee and Lin, 2005) revealed that website design and its 
general outlook had only a minor effect on overall service quality and customer satisfaction. Another study (Than and Grandon, 2002) concluded that the demission of personalization is not a significant predictor of overall service quality and customer satisfaction for online stores. (Robinson et al.,2005) is an interesting study, it concluded that customers perceive online shopping as a common practice and is no longer see it as innovative technology, hence has no effect on customer satisfaction. In consistent to present study findings (Liu et al., 2008) found that, there was no significant relationship between security and privacy on line trust and satisfaction. Finally, although some dimensions of e-service qualities were regarded as "less important" or have "less impact" on customer's satisfaction their role should not be underestimated or ignored.

\section{3. (2). Practical implications of the study}

E-businesses are gradually replacing the traditional businesses. The way of conducting e-businesses is different in that customers do not have direct contact with the product or service. In the e-environment customers, assessment of the product or service is usually based on the general descriptions given to them on the web pages. This study offered comprehensive and combined approach of all constructs influencing customer's satisfaction and customer's loyalty. Findings of this study indicate that all of these constructs have differential impacts on customer's satisfaction and customer's loyalty. Hence, the following managerial implications should be highly adhered to. First, to further improve e-service qualities management priorities need to coincide with customers perceptions. Harmony between management priorities and customers perceptions leads to accurate balancing of constructs away from over or underestimation. In this respect complete, accurate, well-set and accessible information should be given to customers to help them to logically visualize and evaluate online offers. Secondly, Managers should place great emphasis not only on website design but also on website perfect functioning. Customers' perceptions regarding website tools and technologies that facilitates "website perfect functioning" should not be underestimated. Thirdly, e-service providers should develop effective and practical marketing strategies. Such strategies should address the following e- service issues: trustworthy, reliability, responsiveness, security and privacy. Findings of this study confirmed that these issues enhances customer's satisfaction. Fourthly, the proposed combination of dimensions under eight headings allow both practicing managers and customers to better understand the complex nature of the e-environment and consequently react correctly to internet shopping procedures. Fifthly, online service providers should concentrate on all stages of online purchase. Starting from creating positive impressions to the stage of purchasing the product or service. To facilitate these providers need to create safe online environment, protect customers' privacy, guarantee financial security and confirm payment system. Finally, the model developed in this study shows that online customers evaluate the quality of e-service through eight qualities including customer service quality, system quality, information quality, security \&privacy quality, website quality, convenience quality, economic value quality and empathy quality. Practicing managers and decision makers should place great emphasizes on these eight qualities to provide e-service with high-level quality at the same time guarantee more customer satisfaction and loyalty.

\section{3. (3). Conclusions}

Findings of this research work and the empirical findings of large number of reviewed research papers revealed that, online shopping tendency is high all over the world facilitated by rapid internet technology. The researcher emphasized that nearly all demographic characteristics are important determinants of tendency towards online shopping. Moreover, findings of this research showed that customer service quality, system quality, information quality, security \&privacy quality, website quality, convenience quality, economic value quality and empathy quality have differential significant impact on customer's satisfaction and customer's loyalty. The researcher concluded that e-service providers considering entering into this highly competitive market segment need to adopt effective e-marketing strategies, introduce modern and attractive websites, improve their overall e-services, act \& react quickly to e-market needs and e-consumer taste changes, innovate new logistical services. Alignment and continuous improvements of these e-qualities will certainly lead to noticeable increase in customers' satisfaction, customer's loyalty and hence sustaining their businesses.

\section{3. (4). Recommendations}

Based on the findings of this study, the following list of recommendations is given:

1. E-service providers should concentrate more on online customers because the tendency of online shopping and purchasing is continuously increasing.

2. E-service providers should create more innovative and intelligent websites. Such websites should be reachable and easy to use.

3. E-service providers should place great emphasis on other important attributes such as consistency of performance, dependability, function ability and reliability as these attributes have an impact on customers' satisfaction, customer's loyalty 
4. E-service providers should aim to gain more trust by deepening the quality of information provided to online customers. This information should covers all stages of the purchasing decision making process. In this instance, management should work closely with customers to introduce systems that best meet customers' wants and needs at the same time resolve rising problems.

5. E-service providers should create e-shopping systems that highly preserve the issues of security and privacy. Here practical mechanisms of transactions security, acknowledgement, notification, and confirmations can highly enhance the debatable issues of security and privacy.

6. E-service providers should consciously measure customers' satisfaction and customer's loyalty regarding the selection of alternative internet offers, delivery times and so on.

7. E-service providers should regularly evaluate customers' feedback and provide corrective actions in an attempt to keep present customers and attract new ones.

8. E-service providers should use all forms of social media to communicate with online customers. Such communication can be used to speed up online business transactions.

\section{LIMITATIONS OF THE STUDY}

Similar to research of this nature, this study has the following prominent limitations: Firstly, the measurement of study variables and their effect on are based on respondents' perceptions and attitudes while filling the questionnaires. Thus, errors might exist in the data set. Secondly, the study was conducted only in Jordan. This study concentrated on consumers' characteristics for those respondents living in Jordan, therefore, in terms of spread, numbers, behavior and characteristics, respondents in other countries may react differently to the same questions, hence concluding with different results; Thus, the present findings cannot be generalized to other nations. Furthermore, illiterate people were not selected making the sample less representative of the entire population of Jordan. Thirdly, despite the fact that the literature search was extensive, potentially valuable studies may not have been included, looked at and hence, the selection of literature sources may have some elements of bias and subjectivity. Fourthly, the sample size is relatively small for this debatable kind of study this is due to time, resources and willingness to respond constraints. Regarding the willingness to respond the researcher assured respondents that the confidentiality of the information provided will be maintained and such information will only be used for the study purpose. Fifthly, the study used only quantitative approach to find answer to questions through analysis of quantitative data, i.e., the data shown in figures and numbers. Qualitative research methodology on the other hand can help researchers approach fieldwork without being constrained by any predetermined categories of analysis, i.e. qualitative research carries the uniqueness because it does not give conclusions in advance; therefore, qualitative research could be used in foreseeable future research. Finally, it should be noted that the study investigated e- service quality in general terms rather than a specific e-business sector.

\section{FUTURE RESEARCH DIRECTIONS}

This study has confirmed the positive impact of customer service quality, system quality, information quality, security \&privacy quality, website quality, convenience quality, economic value quality and empathy quality on customers' satisfaction and customer's loyalty. However, researchers are highly encouraged to conduct studies on each independent variable to produce more specific and applicable conclusions on the field of online shopping. There is scope to conduct comparative studies across other parts of the world or at least across regional countries in the Middle East. Finally, the researcher recommends the expansion of foreseeable future research in other domains of the e-service.

\section{Acknowledgement}

I am grateful to all respondents for their valuable support and co-operation in filling and returning the questionnaires. Sincere thanks are also, extended to students of Ma'an University College for their great help in the distribution and collection of returns. Extreme thanks to work colleagues for their valuable comments and suggestions throughout the preparation of this study. May God Almighty bless us all.

\section{Competing interests}

Author has declared that no competing interests exist.

\section{References}

A. Chaudhuri, M. B. Holbrook. (2001). "The chain of effects from brand trust and brand affect to brand performance the role of brand loyalty," journal of Marketing, vol. 65, no. 2, pp. 81-93, Doi:101.1509/jmkg.65.2.1.18255 
A. Musiime, R. Malinga. (2011). Internet banking, Consumer adoption and Customer satisfaction, African Journal of Marketing Management, Vol.3, No.10, 261-269.

Agrawal, Anand. (2007). Assessing Service Quality in e-Services: Building up on the Quality Instrumentation, PhD Dissertation, submitted to ICFAI University.

Ahituv, N., “A Systematic Approach Toward accessing the Value of an Information System,” MIS Quarterly, 21, 61-75, 1980.

Akbar, M. M., \& Parvez, N. (2009). Impact of service quality, trust, and customer satisfaction on customer's loyalty. ABAC Journal, 29(1), 24-38.

Alam, S.S., Bakar, Z., Ismail, H.B., and Ahsan, N. (2008). Young Consumers Online Shopping -An Empirical Study. Journal of Internet Business, 5, pp.81-98.

Amoroso, Donald L. and Hunsinger D.Scott, (2008), Analysis of the factors that influence online purchasing, Proc CONISAR, Vol.1.

Ananth, A., Ramesh, R. and Prabaharan, B. (2010) Service Quality Gap Analysis in Private Sector Bank-A Customer Perspective. Indian Journal of Commerce and Management Studies, 2, 245-252.

Asubonteng, P., K.J. McCleary and J.E. Swan, 1996. SERVQUAL revisited a critical review of service quality. J. Services Market. 10: 62-81. DOI: 10.1108/08876049610148602.

Bahram R., Saeed F., and Zeynab R., (2012). Factors Influencing on Customers' E-Satisfaction: A case Study from Iran. Interdisciplinary Journal of Contemporary Research in Business. VOL 3, NO 9.P1502.

Bahram Ranjbarian, Saeed Fathi and Zeynab Rezaei., (2012). Factors Influencing on Customers' E-Satisfaction: A case Study from Iran. Interdisciplinary Journal of Contemporary Research in Business. Viol 3, No 9 , pp. 1496.

Bahram Ranjbarian, Saeed Fathi and Zeynab Rezaei., 2012. Factors Influencing on Customers' E-Satisfaction: A case Study from Iran. Interdisciplinary Journal of Contemporary Research in Business. Viol 3, No 9, pp. 1496.

C. Flavian and M. Guinaliu, and R. Gurrea. (2006) “The role played byperceived usability, satisfaction, consumer trust on website loyalty,"

C.C. Lin. (2003). A critical appraisal of customer satisfaction and e-Commerce, Managerial Auditing Journal, Vol.18, No. 3

Carlson, Jamie \& O'Cass, Aron. (2010). Exploring the relationships between e-service quality, satisfaction, attitudes and behaviors in content-driven e-service web sites. Journal of Services Marketing, 24(2), pp.112 $-127$.

Cass, A. O. (2001). Consumer self-monitoring, materialism and involvement in fashion clothing. Australasian Marketing Journal (AMJ), 9(1), 46-60.

Flavián, C., Guinalíu, M., \& Gurrea, R. (2006). The role played by perceived usability, satisfaction and consumer trust on website loyalty. Information \&Management, 43(1), 1-14.

Chen, C., (2006). Identifying significant factors influencing consumer trust in an online travel site. Inform. Technol. Tourism, 8: 197-214. DOI: 10.3727/109830506778690849

Chiu, Y. B., Lin, C. P., \& Tang, L. L. (2005). Gender differs: assessing a model of online purchase intentions in e-tail service. International Journal of Service Industry Management, 16(5), 416-435.

Christodoulides, G., and Michaelidou, N., (2011) "Shopping Motives as Antecedents of e-Satisfaction and eLoyalty,” Journal of Marketing Management, Vol. 27, No. 1/2:181-197.

Collier, J.E. and Bienstock, C.C. (2006) Measuring Service Quality in E-Retailing. Journal of Service Research, 8, 260-275. https://doi.org/10.1177/1094670505278867.Conference on Information Systems, 2009.

Connolly, R., 2007. Factors influencing Irish consumers' trust in internet shopping: management research news: Communication of emergent international management research, 31, 5 consumer perceptions. Electr. Commerce Res. Applica., 2: 203-215.

Cooper, R. D., and Shindler, S. P. (2007). Business research methods, (9th Ed.). New York: McGraw-Hill.

Corbitt, B.J., Thansankit, T. and Yi, H. (2003). Trust and e-commerce: a study of consumer perceptions. Electronic Commerce Research and Application, 2(3): 203-21

Cronin, J. J. J., \& Taylor, S. A. (1992). Measuring Service Quality: A Reexamination and Extension. Journal of Marketing, 56(3), 55-68.

Cyr, D. (2008). Modeling Website Design Across Cultures: Relationships to Trust, Satisfaction and E-loyalty, Journal of Management Information Systems, Vol. 24, 4:47-72.

L. J. Reid and S. D. Reid. (1993) "Communicating tourism supplier services: building repeat visitor relationships," Communication and Channel Systems in Tourism Marketing, pp. 3-19

D. Branscum and T. Tanaka, "Guarding online privacy,” Newsweek, 
David M. Lane. (2017). Introduction to Linear Regression. Available from: http://onlinestatbook.com/2/regression/intro.html.

DeLone, W. H., and McLean, E. R. (2003) "The DeLone and McLean Model of Information Systems Success: A Ten-Year Update,” Journal of Management Information Systems, Vol. 19, No. 4:9-30.

DeLone, W. H., and McLean, E. R., (2003). "The DeLone and McLean Model of Information Systems Success: A Ten-Year Update,” Journal of Management Information Systems, Vol. 19, and No. 4:9-30

Dholakia, R. R., \& Zhao, M. (2010). Effects of online store attributes on customer satisfaction and repurchase intentions. International Journal of Retail \& Distribution Management, 38(7), 482-496

E. Mustafa, (2011). "Determinants of E-commerce customer satisfaction, trust and loyalty in Saudi ASrabia," Journal of Electronic Commerce Research, vol. 12, no.1

Emery, J.C., "Cost Benefit Analysis of Information Systems," Society for Management Information Systems; the Economic Aspects of Information in the Economic Evaluation of Computer Based Systems, Vol. II, NCC Publication, 1971.Empirical study on online travel service," in Proc. the 17th European

Ganguli, Shirshendu, and Roy, Sanjit Kumar. (2011). Generic technology-based service quality dimensions in banking: Impact on customer satisfaction and loyalty. International Journal of Bank Marketing, 29(2), 168189.

Gummerus, J., V. Liljander, M. Pura, A. Van Riel, (2004). Customer Loyalty to Content-Based Web Sites: The Case of an Online Healthcare

Gwo-Guang Lee. \& Hsiu-Fen Lin. ( 2005) ."Customer perceptions of e-service quality in online shopping". International Journal of Retail\&

H. Li, Y. Liu, and R. Suomi, "Measurement of e-service quality: an

Hair, J.F., Anderson, R.E., Tatham, R.L., \& Black, W.C. (2010). Multivariate Data Analysis, Pearson Education, Upper Saddle River, NJ

Hamilton, S., \& Chervany, N. L. (1981) "Evaluating Information System Effectiveness-Part I: Comparing Evaluation Approaches,” MIS Quarterly, Vol. 5, No. 3:55-69.

Huang, M. H. (2003). Designing website attributes to induce experiential encounters. Computers in Human Behavior, 19(4), 425-442.

Hutchinson, D., \& Warren, M. (2003). Security for internet banking: a framework. Logistic Information Management, 16, (1), 64-73. Information and Management, vol. 43, no. 1, pp. 1-14

Jiang, Pingjun, David B. Jones, and Sharon Javie. (2008). How Third-Party Certification Programs Relate to Consumer Trust in Online Transactions: An Exploratory Study. Psychology \& Marketing, 25 (9), 839-858.

Jin, B., \& Park, J. Y. (2006). The moderating effect of online purchase experience on the evaluation of online store attributes and the subsequent impact on market response outcomes. Advances in consumer June 5, pp. 77$78,2000$.

Kenova, V. and P. Johansson, 2006. Quality Online Banking Services. Doctoral Dissertation, Jönköping University.

Khalifa, M., and Liu, V., (2006) "Online Consumer Retention: Contingent Effects of Online Shopping Habit and Online Shopping Experience,” European Journal of Information Systems, Vol. 16, No. 6:780-792.

Kim, J. and Lee, J. (2002). Critical design factors for successful e-commerce systems. Behavior and Information Technology, Vol. 21

Kim, J. H., \& Lennon, S. J. (2010). Information available on a web site: effects on consumers' shopping outcomes. Journal of Fashion Marketing and Management: An International Journal, 14(2), 247-262.

A. Parasuraman, V. A. Zeithaml, and A. Malhotra, (2005) "E-S-QUAL: Amultiple item scale for assessing electronic service quality," Journal of Service Research, vol. 7, no. 3, pp. 213-233

Kim, J., and Lennon, S.J. (2010). "Information available on a website: Effects on consumers' shopping outcomes," Journal of Fashion Marketing and Management, Vol. 14, No. 2:247

Kim, Jiyoung, Jin, Byonugho, and Swinney L., Jane, (2009), the role of etail quality, e-satisfaction and e-trust in online loyalty development process, Journal of Retailing and Consumer Service 16, pp 239-247.

Kim, M., Kim, J. H., and Lennon, S. J. (2011). E-service attributes available on men's and women's apparel web sites. Managing Service Quality, 21(1): 25-45.

Kitapci, O., Akdogan, C. and Dortyol, İ.T. (2014) The Impact of Service Quality Dimensions on Patient Satisfaction, Repurchase Intentions and Word-of-Mouth Communication in the Public Healthcare Industry. Procedia-Social and Behavioral Sciences, 148, 161-169.

Kueh, K. and Voon, B.H. (2007) Culture and service quality expectation: Evidence from generation Y consumers in Malaysia. Managing Service Quality. 17(6), pp. 656-680. 
Kuo, Y.F., Wu, C.M., and Deng, W.J. (2009). The relationships among service quality, perceived value, customer satisfaction, and post-purchase intention in mobile value added services. Computers in Human Behavior, $25,887-896$.

Lee, G.-G. In addition, Lin, H.-F. (2005) Customer Perceptions of E-Service Quality in Online Shopping. International Journal of Retail \& distribution Management, 33, 161-176. https://doi.org/10.1108/09590550510581485

Lee, J. A., \&Kacen, J. J. "Cultural influences on consumer satisfaction with impulse and planned purchase decisions," Journal of Business Research, Vol. 61, No. 3:265-272, 2008.

Li, H. and Suomi, R. (2009) A Proposed Scale for Measuring E-Service Quality. International Journal of U- and E -Service, Science and Technology, 2, 1-10.

Li, Y. (2009). Measuring e-commerce dimensions. Journal of Computer Information Systems, 2-12.

Liao, C., Palvia, P., \& Lin, H. N. (2006). The roles of habit and web site quality in e-commerce. International Journal of Information Management, 26(6), 469-483.

Liu, C., Arnett, K.P., Capella, L.M., and Taylor, R.D. (2001), "Key Dimensions of Web Design as Related to Consumer Response,” Journal of Computer Information Systems, Vol. 42:47-69.

Liu, X., He, M., GAO, F., \& Xie, P. (2008). An empirical study of online shopping customer satisfaction in China: a holistic perspective. International Journal of Retail \&Distribution Management, 36(11), 919-940.

Livari, J., (2005) .An empirical test of the Delone-McLean Model of information system success. The DATA BASE for Advances in Information Systems, 36(2). Loyalty to e-loyalty: A conceptual framework," Journal of Economic

M. D. Uncles, G. R. Dowling, and K. Hammond. (2003) "Customer loyalty and customer loyalty programs," Journal of Consumer Marketing, vol. 20, no. 4, pp. 294-316

M. Fasanghari, and F. Roudsari H. (2008). The Fuzzy Evaluation of E-Commerce Customer Satisfaction, World Applied Science Journal, Vol. 4, No.2, 164-168.

M. P. Neghab S. M. Heravi and M. Kahani. (2013). Simulation and Optimization of Affective Causes on Quality of Electronic Services, Journal of Mathematics and Computer Science, Vol. 7, 23-32.

Madad Ali, Fahad Asmi, Md. Mashiur, Naveed Malik, Muhammad Ahmad, (2017). Evaluation of E-Service Quality through Customer Satisfaction (a Case Study of FBR E-Taxation). Open Journal of Social Sciences, 2017, 5, 175-195.http://www.scirp.org/journal/jss

Madad Ali, Fahad Asmi, Md. Mashiur, Naveed Malik, Muhammad Ahmad, (2017). Evaluation of E-Service Quality through Customer Satisfaction (a Case Study of FBR E-Taxation). Open Journal of Social Sciences, 2017, 5, 175-195.http://www.scirp.org/journal/jss

Madu, C.N., and Madu, A.A. (2002). "Dimensions of e-Qaulity," International Journal of Quality and Reliability Management, Vol. 19, No. 3:264-259.

Martinelli, E., and Balboni, B. (2012). Retail service quality as a key activator of grocery store loyalty. The Service Industries Journal, 32, 2233-2247.

McKinney, V., Yoon, K., and Zahedi, F.M. (2002) "The Measurement of Web-Customer Satisfaction: An Expectation and Disconfirmation Approach,” Information Systems Research, Vol. 13, No. 3:296-315.

McKinney, V., Yoon, K., and Zahedi, F.M. (2002). "The Measurement of Web-Customer Satisfaction: An Expectation and Disconfirmation Approach,” Information Systems Research, Vol. 13, No. 3:296-315.

Michel S., Bowen D., and Johnston, R. (2009). Why service recovery fails: Tensions among customer, employee, and process perspectives. Journal of Service Management, 20, 253 - 273.

Morton, F.S., (2006) “Consumer Benefit from Use of the Internet,” NBER Innovation Policy \& the Economy (MIT Press), Vol. 6, No. 1:67-90.

Mozaheb, A., Alamolhodaei, S.M.A., Fotouhi Ardakani, M. (2015). A Study of Influencing Factors of Customer Relate Ship Management On Business Performance In Small And Medium Business (SMEs), International Journal of Academic Research in Accounting, Finance and Management Sciences., Vol. 5, No.2, pp. 4252. ISSN: $2225-8329$.

Ndubisi, N.O. (2006) A Structural Equation Modeling of the Antecedents of Relationship Quality in the Malaysia Banking Sector. Journal of Financial Services Marketing, 11, 131-141. https://doi.org/10.1057/palgrave.fsm.4760033 No. 3, pp. 185-9.

Oliveria, P., Roth, A.V. and Gilland W. (2002). Achieving competitive capabilities in e-services Technology Forecasting \& Social Change, 69(2002), 721739.P New York. Kotler, Marketing Management, Prentice Hall, Inc.,

P. Rauyenruan and K. E. Miller. (2007). "Relationship quality as a predictor of B2B customer loyalty," Journal of Business research, vol. 60 , no. 1, pp. $21-31$ 
Parasuraman, A., Zeithaml, V.A. and Berry L.L. (1985) A conceptual model of service quality and its implications for future research. Journal of Marketing. 49, autumn, 41-50.

Parasuraman, A., Zeithaml, V.A. and Berry L.L. (1988) SERVQUAL: A multiple-item scale form consumer perceptions of service quality. Journal of Retailing. 64(1), pp. 12-40.

Parasuraman, A., Zeithaml, V.A. and Berry, L.L. (1985) A conceptual Model of Service Quality and Its Implications for Future Research. The Journal of Marketing, 49, 41-50. https://doi.org/10.2307/1251430

Parasuraman, A., Zeithaml, V.A. and Malhotra, A. (2005). E-S-QUAL: a multiple-item scale for assessing electronic service quality. Journal of Service Research, 7(3), 213-33.

Parasuraman, A., Zeithaml, V. A., \& Berry, L. L. (1988) SERVQUAL: A Multiple-Item Scale for Measuring Consumer Perceptions of Service Quality, Journal of Retailing, Vol. 64, No. 1:12-4.

Peterson, R. A., \& Merino, M. C. (2003). Consumer information search behavior and the Internet. Psychology \& Marketing, 20(2), 99-121.

Peterson, Robert A., Sridhar Balasubramanian and Bart J.Bronnenberg, (1997), exploring the Implications of the Internet for Consumer Marketing, Journal of the Academy of Marketing Science, 25 (fall): pp.329-346.

R. E. Anderson and S. S. Srinivasan. (2003) "satisfaction and e loyalty: a contingency framework," Psychology and Marketing, vol. 20, no. 2, pp. $123-138$

R. Mekovec, K. Kero. (2007. E-Service quality: a case study of Varazdin County, 26th International Conference on Organizational Science Development creative organisation, March 28-30, (2007), Protozoa, Slovenia.

Raosoft (2004), Raosoft Sample Size Calculator, Retrieved from Internet on 26 February 2019,http://www.raosoft.com/samplesize.html

Reibstein, D.J. (2002). What attracts customers to online stores, and what keeps them coming back? Journal of the Academy of Marketing Science, 30, pp. 465-473.Research, 33, 203.

Robinson Jr., L, Marshall, G.W., and Stamps, M.B. (2005). "Sales force use of technology: antecedents to technology acceptance," Journal of Business Research, Vol. 58, and No. 12:1623-1631

S. Ghane, M. Fatian, and M. R. Gholamian. (2011) "Full relationship among e-satisfaction, e-trust, e-service quality and e-loyalty: the case of Iran e-banking," Journal of Theoretical and Applied Information Technology, 15 th November, vol. 33 , no. 1

Santos, J. (2003), "E-service quality: a model of virtual service quality dimensions”, Management Service Quality, Vol. 13 No. 3, pp. 233-46.

Saunders, M., Lewis, P. and Thorn hill, A. (2003). Research methods for business students (3rdEd) Harlow, England: Financial Times Prentice Hall.

Sedera, D., G. Gable and T. Chan, 2004. A factor and structural equation analysis of the enterprise systems success measurement model. In Proceedings of the Twenty-Fifth International Conference on Information Systems (APPELGATEL, GALLIERS R and DEGROSS JI, Eds), p 449, Association for Information Systems, Washington, DC, USA

Shih, Y. Y., \& Fang, K. (2006). Effects of network quality attributes on customer adoption intentions of internet banking. Total Quality Management \& Business Excellence, 17(1), 61-77.

Siriluck, R., \& Speece, M. (2003). Barriers to internet banking adoption: a qualitative study among corporative customers in Thailand. International Journal of Bank Marketing, 21, (6), 312-23

Sri Astuti, Christina Lipuringtyas, and Tetty Rimenta, (2013). Factors Influencing Customer Loyalty toward Online Shopping. International Journal of Trade, Economics and Finance, Vol. 4, No. 3, June.

Srinivasan, S. S., Anderson, R., \& Ponnavolu, K. (2002).Customer loyalty in e-commerce: an exploration of its antecedents and consequences. Journal of retailing, 78(1), 41-50.

Stacie, P., W. DeLone and E. McLean: Measuring information systems success: models, dimensions, measures, and interrelationships. European Journal

Sun, H. (2010) "Transferring attributes of e-commerce systems into business benefits: A relationship quality perspective”, Journal of Electronic Commerce Research, Vol. 11, No. 2:92-109.

Tan, C.W., Benbasat, I. and Cenfetelli, R.T. (2008) Building Citizen Trust towards E-Government Services: Do High Quality Websites Matter? 217.

Than, C.R. and Grandon, E. (2002), "An exploratory examination of factors affecting online sales", Journal of Computer Information Systems, Vol. 42 No. 3, pp. 87-93.

Than, C.R. and Grandon, E. (2002), "An exploratory examination of factors affecting online sales", Journal of Computer Information Systems, Vol. 42 No. 3, pp. 87-93

Tianxiang Sheng Chunlin Liu, (2010),"An empirical study on the effect of e-service quality on online customer satisfaction and loyalty", Nankai Business Review International, Vol. 1 Issue 3 pp. 273 - 283 
V. Sundaram 1, D. Ramkumar 2, P.Shankar. (2017). Impact of E-Service Quality on Customer Satisfaction and Loyalty Empirical Study in India Online Business. KINERJA Volume 21, No. 1, 2017 Page. 48-69

V.A. Zeithaml, A. Parasuraman, A. Malhotra. (2002). Service quality delivery through websites: a critical review of extant knowledge, J. Acad. Market. Sci. 30 (4) 362-375

Van Riel, A.C.R., Liljander, V.and Jurriens , P.(2001), Exploring consumer evaluations of e-services : a portal site , International Journal of service Industry Management, Vol.12 No.4, pp.359-77.

Wan, P. Y. K., and Cheng, E. I. M. (2011). Service quality of Macao's world heritage site. International Journal of Culture. Tourism and Hospitality Research, 5(1): 57-68.

Wan, P. Y. K., and Cheng, E. I. M. (2011). Service quality of Macao's world heritage site. International Journal of Culture. Tourism and Hospitality Research, 5(1): 57-68.

Wang Y, Lo HP, Hui YV (2003) the antecedents of service quality and product quality and their influences on bank reputation: evidence from banking industry in China. Managing Service Quality 13: 72-83.

Wang, Ming (2003), Assessment of e-service quality via e-satisfaction in e-commerce globalization, EJISDC, Vol.11, No.10, pp. 1-4.

Wiertz, C., De Ruyter, K., Keen, C., \& Streukens, S. (2004). Cooperating for service excellence in multichannel service systems: An empirical assessment. Journal of Business Research, 57(4), 424-436.

Williams, P., and Neumann, E. (2011). Customer satisfaction and business performance: a firm-level analysis. Journal of Services Marketing, 25, 20-32.

Wirtz, B. W., \& Lihotzky, N. (2003). Customer retention management in the B2C electronic business. Long Range Planning, 36(6), 517-532.

Wolfinbarger, M. and Gilly, M.G. (2003), "eTailQ: dimensional zing, measuring and predicting etail quality", Journal of Retailing, Vol. 79 No. 3, pp. 183-98.

Wolfinbarger, M. and Gilly, M.G. (2003), "eTailQ: dimensionalzing, measuring and predicting etail quality", Journal of Retailing, Vol. 79 No. 3, pp. 183-98.

Yang, Z. (2001), "Customer perceptions of service quality in internet-based electronic commerce", Proceedings of the 30th EMAC Conference, Bergen, pp. 8-11.

Yang, Z. (2001), "Customer perceptions of service quality in internet-based electronic commerce", Proceedings of the 30th EMAC Conference, Bergen, pp. 8-11.

Yang, Z. and Jun, M. (2002), "Consumer perception of e-service quality: from internet purchaser and nonpurchaser perspectives”, Journal of Business Strategies, Vol. 19 No. 1, pp. 19-41.

Yang, Z. and M. Jun 2002. Consumer perception of eservice quality: From internet purchaser, non-development, and managerial implications. J. Bus. Strategies, 19: 19-41.

Yang, Z., \& Jun, M. (2008). Consumer perception of e-service quality: From internet purchaser to non-purchaser perspectives. Journal of Business Strategies, 25(2), 59-84.

Zeithaml, V. A., Parasuraman, A., \&Malhotra, A. (2002) Service Quality Delivery through Web Sites: A Critical Review of Extant Knowledge, Journal of the Academy of Marketing Science, Vol. 30, No. 4:362-375.

Zeithaml, V.A. (2002), "Service excellent in electronic channels", Managing Service Quality, Vol. 12 No. 3, pp. $135-8$.

Zhang, X., Prybutok, V., \& Huang, A. (2006). An empirical study of factors affecting e-service satisfaction. Human Systems Management, 25(4), 279-291.

Zhilin, Y., Minjoonjun. and Peterson, R.T., 2004. Measuring Customer Perceived Online service quality - Scale development and managerial implications. International Journal of Operations \& Productions management, 24(11), pp. 1149-1174.

Zhu, F.X., Wymer, W. and Chen, I. (2002), "IT-based services and service quality in consumer banking", International Journal of Service Industry Management, Vol. 13 No. 1, pp. 69-90.

Zins, A., (2001). Relative Attitudes and Commitment in Customer Loyalty Models: Some Experience in the Commercial Airline Industry.

Mohammed Raja Salah (PhD-Business Administration): Is a senior lecturer in Administrative and Financial department, Ma'an University College, Al-Balqa applied University, Ma'an- Jordan. Research interests include Time management in Jordanian Companies, Performance evaluation in Textiles factories in Jordan. The influence of rewards on employees' performance, marketing human resources issues like training, development and productivity and E-service qualities. 